\title{
Copyright Law's Broken Rear Window: An Appraisal of Damage and Estimate of Repair
}

\author{
Daniel A. Saunders $\uparrow$
}

Few Supreme Court cases have engendered as much concern and debate within the entertainment industry as Stewart $\mathrm{v}$. Abend. That decision determined the relative rights of holders of copyrights in derivative motion pictures and in the source material on which those films are based. Industry insiders have predicted that the decision will significantly change the way business is conducted and may result in temporary or permanent withdrawal of countless classic motion pictures from distribution. This Comment begins by arguing that the legal foundations of the Stewart opinion are questionable in light of the relevant copyright statutes and precedents. It then argues the failure of the decision from a policy perspective and contends that the decision is inconsistent both with the goals of copyright protection as set forth in the Constitution and with the realities of motion picture production. Having presented the case for congressional intervention, the Comment proposes remedial legislation and evaluates arguments that the legislation would violate the Due Process and Takings Clauses of the Fifth Amendment. The Comment concludes that the proposed legislation is both constitutional and necessary to protect the interests of motion picture studios and the American viewing public.

\section{INTRODUCTION}

FADE IN on a video rental store in Anytown, U.S.A. The time is the present. Joe Filmbuff and his young son have been looking through the stacks for several minutes. Joe approaches the counter.

Clerk: May I help you?

Joe: I'in looking for a wonderful inovie I remember from my childhood. I was hoping to watch it with my son tonight.

Clerk: What's the inovie?

Joe: $\quad$ It's called Classic of Classics.

$\dagger$ A.B. 1983, Princeton University; J.D. candidate 1992, Boalt Hall School of Law, University of California at Berkeley. I wish to thank Professor Stephen Barnett, Professor Andrea Peterson, and David Nimmer for their valuable comnients on and challenges to earlier drafts of this Comnient. Thanks also to Mari Mazour, Debbie Beck, Janis Albertson, and the hardworking staff of the Califormia Law Review. A special thanks to Jennifer Upham for her patience, her support, and her coniputer. 
Clerk: Ah yes, that was a marvelous film. Stellar performances, magnificent direction, thrilling screenplay. Won quite a few Academy Awards that year, as I recall.

Joe: Yes, that's the one. Do you have it?

Clerk: Afraid not, sir. You won't be able to see that one again until 2043.

CUT TO:

Max Mogul's Hollywood studio office. Steve Author, a man in his seventies, sits across the desk from Max.

Max: Stevie, baby, this story of yours is to die for. I can't believe in twenty years nobody's ever made a movie of it. It's a gold mine, sweetheart. Gonna be a box office smash.

Steve: That's wonderful. I could certainly use the money I'll get from selling the rights.

Max: Whoa, hold the phone, Stevie, buddy, 'fraid I can't help you there. Don't take this personal, but I can't even think about doing a deal on this picture for another eight years. Unless you'd be willing to die first.

FADE OUT

The foregomg is not a script from The Twilight Zone. It is a dramatization of the very real workings of American copyright law as apphed by the Supreme Court recently in Stewart v. Abend. ${ }^{1}$ In that case the author of the copyrighted short story It Had to Be Murder assigned motion picture rights in the story and agreed to reassign the rights to the same party when the copyright came up for renewal. A derivative work, ${ }^{2}$ Alfred Hitchcock's film Rear Window, was produced by the eventual owners of the motion picture rights, but the author of the story died before renewing his copyright and reassigning the rights. Resolving a split between the Second and Nimth Circuits, the Court held that the proprietors of the derivative work could be sued for copyright infringement if they contmued to exploit that work without obtaining rights in the underlying work's ${ }^{3}$ renewal term from the author's successors, despite the author's contractual agreement to assign the renewal rights.

The Court's decision represents a clear and final pronouncement on the relative rights of owners of copyrights in underlying and derivative material and nullifies a precedent on which motion picture studios and

1. 110 S. Ct. 1750 (1990). (1988)

2. A derivative work is a work based on one or more preexisting works. $17^{4}$ U.S.C. $\S 101$

3. The term "underlying work" is used herein to refer to the preexisting work upon which a derivative work is based. 
entertainment law practitioners have rehed for over a decade. ${ }^{4}$ The entertainment industry greeted the decision with alarm, predicting that hundreds of classic and not-so-classic films would be removed from circulation and withheld froin the public until the copyright terms in their underlying works expired. 5

The Stewart decision is still too recent to permit any accurate empirical data regarding its practical effect, but solne of the dire forecasts that the decision engendered appear to have proven accurate. Films are indeed becoming unavailable to the American public, and some may never be seen again. Authors and composers of underlying works subject to the Stewart rule are finding theinselves without a market for the incorporation of their works into motion pictures. Movie studios holding copyrights in successful films are being forced to pay large sums to proprietors of underlying works, many of whoin had nothing to do with the creation of either the source material or the derivative work. In all of these real effects, the Stewart decision is contrary to the purposes of copyright legislation as expressed in the Constitution and by Congress and the courts.

Despite its negative ramifications, the Stewart decision was based on a tenable reading of the relationship between two ainbiguous provisions of the 1909 Copyright Act. ${ }^{6}$ The situation is further complicated because the vague drafting of the relevant provisions was carried forward into the 1976 Copyright Act's general revision of copyright law. ${ }^{7}$ While the best lope of correcting the harmful consequences of the Stewart decision lies in congressional action, ${ }^{8}$ any proposed anendinent to the Copyright Act is likely to face a constitutional challenge. Because the Court has now defined the extent and relation of certain property rights, any attempt to

4. See Brief of Amicus Curiae Submitted by Columbia Pictures Indus. at 5-6, Stewart v. Abend, 110 S. Ct. 1750 (1990) (No. 88-2102) [hereinafter Studios' Amicus Brief] (submitted by numerous inotion picture studios in support of petitioners).

5. See, e.g., Robert G. Sugarman \& Joseph P. Salvo, Fate of Many Hollywood Classics Ensnarled in Legal Conundrum, NAT'L L.J., June 4, 1990, at 22; Bill Holland, 700 Films May Face Copyright Scrutiny, BillboARd, May 5, 1990, at 1; Charles J. Sanders \& Susan O. Mann, High Court Solves Hitchcock Mystery: Overrules 'Rohauer' in 'Stewart v. Abend,' N.Y. L.J., May 8, 1990, at 1.

6. Copyright Act of 1909 , ch. 320,35 Stat. 1075 (codified as amended at 17 U.S.C. $\$ \S 1-216$ (1976)) [hereinafter cited as 1909 Act]. The 1909 Act was amended and codified into title 17 of the United States Code by Act of July 30, 1947, ch. 391, 61 Stat. 652 (1947).

7. Copyright Revision Act of 1976, Pub. L. No. 94-553, 90 Stat. 2545 (1976) (codified at 17 U.S.C. $\$ \$ 101-810$ (1988)) [hereinafter cited as 1976 Act].

8. This Comment will put aside the remote possibility of a Supreine Court overruling and proceed with the assumption that Stewart represents a final judicial accoinınodation of the coinpeting interests of underlying - and derivative-work owners. Once this assuinption is accepted, congressional intervention becomes the only means of reinedying the uudesirable policy consequences of the decision. 
abrogate those rights could arguably constitute a deprivation of property in violation of the Due Process and/or Takings Clauses.

Part I of this Comment summarizes the Stewart decision and the precedential and statutory bases underlying the Supreine Court's reasoning. This Part approaches the decision from a purely legal standpoint and argues that neither statute nor precedent mandated the Court's holding. Part II views Stewart from a policy perspective and examines the potentially serious consequences of the decision. It argues that Stewart is inconsistent with the estabhished policy goals of copyright law and suggests why Congress should atteinpt to counteract the decision's effects. Part III proposes corrective legislation and examines the argument that retroactive amendment of the Copyright Act would violate the protections of the Due Process and Takings Clauses of the Fifth Amendinent. The Comment concludes that the proposed legislation would be both desirable and constitutional; it would leave a potential loophole, however, that only a Supreme Court overruling could remedy.

\section{I}

The Window Shatters: Legal Background AND THE STEWART DECISION

"I wish I could be creative."

"You are. You have great talent for creating difficult situations." Grace Kelly and James Stewart in Rear Window ${ }^{9}$

\section{A. The Copyright Acts of 1909 and 1976}

The United States Constitution authorizes Congress " $[\mathrm{t}] \mathrm{o}$ proinote the Progress of Science and useful Arts, by securing for limited Times to Authors and Inventors the exclusive Right to their respective Writings and Discoveries." 10 Pursuant to this power, Congress has, for the last two centuries, provided authors with a limited nonopoly by granting them certain exclusive rights in their works for limited periods. These rights nray be assigned or granted by the copyright owner. ${ }^{11}$

The Stewart decision turned on an attempted reconciliation of two arguably inconsistent provisions of the 1909 Copyright Act: section 7, covering copyrights for derivative works, and section 24 , dealing with the renewal term. This Section examines these two provisions and their

9. REAR Window (Paramount 1954).

10. U.S. CoNST. art. I, $\S 8$, cl. 8.

11. 1909 Act, 17 U.S.C. $\S 28$ (1976) (originally enacted as Act of Mar. 4, 1909, ch. 320, $\$ 42$, 35 Stat. 1075, 1084); 1976 Act, 17 U.S.C. $\S 201$ (d) (1988). 
counterparts in the 1976 general revision. ${ }^{12}$

\section{Derivative Works}

The right to prepare derivative works based on the copyrighted work is one of the exclusive rights granted to authors under both the 1909 and 1976 Acts. $^{13}$ The 1976 Act defines a "derivative work" as "a work based upon one or more preexisting works, such as a translation, musical arrangement, dramatization, fictionalization, inotion picture version, sound recording, art reproduction, abridgment, condensation, or any other form in which a work inay be recast, transformed, or adapted."14 Professor Nimmer defined a derivative work as a work that would be infrimging but for the public-donam status of the underlying work or the consent of the underlying work's copyright owner. ${ }^{15}$ The creator of a noninfrimging derivative work-that is, a derivative work based on an underlying work in the public domam or created pursuant to the consent of the owner of the copyright in the underlying work-may obtain a copyright on the derivative work independent of that on the underlying work as long as the derivative work meets the fundamental "originality" requirenent for copyright protection. ${ }^{16}$

Section 7 of the 1909 Act provided that noninfringing derivative works were to be "regarded as new works subject to copyright" 17 with an important limitation:

the publication of any such new works shall not affect the force or valid-

ity of any subsisting copyright upon the natter enployed or any part

12. The Stewart Court did not determine whether the hitigation was governed exclusively by the 1909 Act or the 1976 Act. See infra note 351.

13. 1909 Act, 17 U.S.C. \$1(b) (1976) (originally enacted as Act of Mar. 4, 1909, ch. 320, $\S 1$ (b), 35 Stat. 1075, 1075); 1976 Act, 17 U.S.C. $\$ 106(2)$ (1988). For a discussion of the historical evolution of derivative rights, see Paul Goldstein, Derivative Rights and Derivative Works in Copyright, 30 J. CoPYRIGHT SOC'Y U.S.A. 209, 211-15 (1983).

14. 1976 Act, 17 U.S.C. $\$ 101$ (1988). The term "derivative work" was not used in the 1909 Act. Section 7 of that Act referred geuerally to "compilations or abridgments, adaptations, arrangements, dramatizations, translations, or other versions of works." 1909 Act, 17 U.S.C. $\$ 7$ (1976) (originally enacted as Act of Mar. 4, 1909, ch. 320, § 6, 35 Stat. 1075, 1077). The first reported case to use the phrase "derivative work" was Nom Music, Inc. v. Kaslin, 343 F.2d 198, 200 (2d Cir. 1965). For the purposes of this Comment, the terminology of the 1976 Act will be applied throughout.

15. 1 Melville B. Nimmer \& David Nimmer, Nimmer on Copyright $\S 3.01$, at $3-3$ (1991).

16. Id. $\S 3.03$, at 3-10. The "originality" standard does not include requirements of novelty, ingenuity, or aesthetic merit. H.R. REP. No. 1476, 94th Cong., 2d Sess. 51 (1976) [hereinafter 1976 HOUSE REPORT]; see 1 NIMMER \& NIMMER, supra note $15, \S 2.01$ [A]. All that the law requires is that the work for which proteetion is sought not be copied from some other source and that it possess a minimal degree of creativity. See Feist Publications, Inc. v. Rural Tel. Serv. Co., 111 S. Ct. 1282, 1287 (1991); Sheldon v. Metro-Goldwyn Pictures Corp., 81 F.2d 49 (2d Cir.), cert. denied, 298 U.S. 669 (1936).

17. 1909 Act, 17 U.S.C. $\S 7$ (1976) (originally enacted as Act of Mar. 4, 1909, ch. 320, § 6, 35 Stat. 1075, 1077 (emphasis added)). 
thereof, or be construed to imply an exclusive right to such use of the original works, or to secure or extend copyright in such original works. ${ }^{18}$

The 1976 Act contains a similar restriction:

The copyright in a ... derivative work extends only to the inaterial contributed by the author of such work, as distinguished from the preexisting material einployed in the work, and does not imply any exclusive right in the preexisting material. The copyright in such work is independent of, and does not affect or enlarge the scope, duration, ownership, or subsistence of, any copyright protection in the preexisting material. ${ }^{19}$

The two provisions make equally clear that the copyright in an underlying work is undiluted by the work's mcorporation into a derivative work. Only the 1976 section, however, directly addresses the scope of protection afforded to the derivative work by its copyright-that is, protection only of the new inaterial added by the creator. ${ }^{20}$ In contrast, the "new works" language of section 7 of the 1909 Act can be imterpreted to mean that the copyright in a derivative work protects the entire work, thereby creatimg overlapping claims to the source inaterial. ${ }^{21}$ Although the language of section 7 inakes clear that a grant of derivative rights does not convey exclusive rights freely to use the underlymg work-for example, by creating further derivative works without consent-this does not preclude construing the grant as giving the derivative-work owner a nonexclusive right permitting the continued use of the underlying work to the extent it has been incorporated in the new work under a valid grant from the underlying-copyright owner. ${ }^{22}$ The "force or validity" of the underlying copyright would remain unaffected in the sense that the holder of the copyright in that work would retain all rights that had not been transferred or hicensed, including the right to authorize further derivative works.

\footnotetext{
18. Id.

19. 1976 Act, 17 U.S.C. $\S 103(b)$ (1988).
}

20. See 1976 House REPORT, supra note 16 , at 57:

Section 103(b) is ... intended to define, more sharply and clearly than does section 7 of the present law, the important interrelationship and correlation between protection of preexisting and of "new" Inaterial in a particular work. The inost important point here is one that is commouly misunderstood today: copyright in a "new version" covers only the inaterial added by the later author, and has no effect one way or the other on the copyright or public domain status of the preexisting inaterial.

21. The "force or validity" clause of $\S 7$ does not require a different reading: the Second Circuit has read the clause in hight of its legislative history as ensuring only that the publication of a derivative work without valid copyright protection would not affect or forfeit the copyright in the underlying work. Rohauer v. Killiam Shows, Inc., 551 F.2d 484, 488-90 (2d Cir.), cert. denied, 431 U.S. 949 (1977); see infra text accoinpanying notes 83-86.

22. Rohauer, 551 F.2d at 492. 


\section{Duration of Copyright: Renewal and Termination}

\section{a. The 1909 Act: Renewal}

Like its predecessors, ${ }^{23}$ the 1909 Act established a two-term system of copyright protection. Section 24 of the Act provided for an initial term of twenty-eight years from the date of first pubhication; within one year prior to the expiration of the original term, the author could renew the copyright for an additional twenty-eight years by submitting an application to the Copyright Office. ${ }^{24}$ The right of renewal belonged to the author, if living. If the author was deceased, the Act mandated a bequest to the author's widow, widower, or children; if none of these were hiving, the renewal could be obtained by the author's executors or next of kin. ${ }^{25}$

The renewal term was intended to protect authors and those dependent upon them from inıprovident bargains. An author in a weak bargaining position might assign for a noininal sum a copyright that later proves to be highly valuable; the renewal term gave authors and their families a second bite at the apple when their negotiating power iniproved. ${ }^{26}$ The compulsory bequest, by favoring the author's heirs over assignees, served the further purpose of securing to the author's family the opportunity to exploit the work if the author died before renewal. ${ }^{27}$

The Supreme Court has vacillated in its willingness to apply the paternalistic objectives of the two-term system. In 1923 the Court held that the exercise of renewal rights does not smiply extend the original term but creates a completely new estate unrestricted by any rights,

23. The first American copyright legislation was passed by the first Congress in 1790. Act of May 31, 1790, ch. 15, 1 Stat. 124. It provided for an initial 14-year term of copyright protection with the opportunity of renewing the copyright for an additional 14-year renewal term. The renewal could be obtained by the author or his executors, administrators, or assigns, and thus followed the author's estate or inter vivos transfer as would any other property. Id. $\S 1,1$ Stat. 124, 124. However, under the Act of 1831 the right to renew a copyright was given to the author, if living, or if the author died prior to the commencenient of the renewal term to the author's spouse and children. Act of Feb. 3, 1831, ch. 16, § 2, 4 Stat. 436, 436 (1831); see Seymour M. Bricker, Renewal and Extension of Copyright, 29 S. CAL. L. REV. 23, 24 (1955) (summarizing the Acts of 1790 and 1831).

24. 1909 Act, $\S 24,35$ Stat. 1075, 1080-81.

25. Id.

26. As the House Report states:

It not infrequently happens that the author sells his copyright outright to a publisher for a coniparatively sniall sum. If the work proves to be a great success and lives beyond the term of twenty-eight years, your committee felt that it should be the exclusive right of the author to take the renewal term, and the law should be framed as is the existing law, so that he could not be deprived of that right.

H.R. REP. No. 2222, 60th Cong., 2d Sess. 14 (1909); see also 2 NIMMER \& NIMMER, supra note 15, $\S 9.02$, at 9-26 ("[U]nlike real property and other forms of personal property, [a copyright] is by its very nature incapable of accurate nonetary evaluation prior to its exploitation.").

27. See DeSylva v. Ballentine, 351 U.S. 570, 582 (1956) ("Sincc the author cannot assign his family's renewal rights, [the renewal provision] takes the form of a conipnlsory bequest of the copyright to the designated persons."). 
interests, or licenses granted under the original copyright. ${ }^{28}$ This gave the author a nearly unrestricted "second chance." The Court significantly limited this doctrine twenty years later, however, by lolding in Fred Fisher Music Co. v. M. Witmark \& Sons ${ }^{29}$ that the 1909 Act did not prevent authors froin assigning their renewal rights in futuro-that is, during the original copyright tern. ${ }^{30}$ By refusing to recognize that authors are "congenitally irresponsible" children incapable of protecting theinselves, ${ }^{31}$ Fred Fisher undermined the policy behind the renewal reversion. The decision allowed authors witl weak bargaining power due to the unproven economic value of their work-the precise group the renewal provisions were enacted to protect-to assign their renewal rights together with the original term when forced to do so to effect a sale. ${ }^{32}$

The freedoin of contract that Fred Fisher afforded authors was not absolute, lowever, for the riglits of the beneficiaries designated by section 24 are separate and independent froin those of the author and cannot be defeated or diminished by any act on the author's part. ${ }^{33}$ Accordingly, the Supreme Court held in Miller Music Corp. v. Charles N. Daniels, Inc. ${ }^{34}$ that a preinature assigninent of renewal riglits grants only an expectancy, the fulfillment of which is dependent upon the author's surviving to the beginning of the twenty-eighth year of the first tern..$^{35}$ An author's death prior to the vesting of renewal rights terminates this contingent interest and vests the renewal in the autloor's statutory successors. ${ }^{36}$ As the Court stated:

Until [the renewal period] arrives, assignees of renewal rights take the risk that the rights acquired may never vest in their assignors. A purchaser of such an interest is deprived of nothing. Like all purchasers of contingent interests, he takes subject to the possibility that the contin-

28. Fox Film Corp. v. Knowles, 261 U.S. 326, 327 (1923); see Bricker, supra note 23, at 27-28.

29. 318 U.S. 643 (1943).

30. Id. at 657 (refusing to "import[ ] into Congressional legislation a denial to authors of the freedoin to dispose of their property possessed by others").

31. Id. at 656.

32. Virginia E. Lohmann, Note, The Errant Evolution of Termination of Transfer Rights and the Derivative Works Exception, 48 OH1O ST. L.J. 897, 900-01 (1987); 2 NiMmer \& NiMmER, supra note $15, \S 9.06[\mathrm{~B}]$, at 9-72. However, even while enforcing the alienability of renewal interests, the Court suggested that unconscionable bargains would not be enforceable. Fred Fisher, 318 U.S. at 656-57.

33. See Bricker, supra note 23 , at 33.

34. 362 U.S. 373 (1960). The case involved joint authors of a song, one of whom sold his renewal rights to Miller Music and subsequently died before the expiration of the initial term. He left no widow or children, and his executor clained the renewal on behalf of the deceased's legatees (who assigned their rights to the coauthor).

35. Id. at 375 .

36. Id.; see Malcolm L. Mimms, Jr., Reversion and Derivative Works Under the Copyright Acts of 1909 and 1976, 25 N.Y.L. SCH. L. REv. 595, 602 (1980). 
gency may not occur. ${ }^{37}$

\section{b. The 1976 Act: Termination}

The 1976 Act replaced the two-term copyright protection system of the 1909 Act with a unitary term that extends for the life of the author plus fifty years. ${ }^{38}$ The reasons for this significant change, as enunierated in the House Committee Report, included accounting for increased life expectancy, developinents in commuincations inedia with a concomitant lengthening of the commercial lives of inany works, and bringing the systein of copyright protection into conformity with those of foreign countries. $^{39}$ The Committee also noted the "substantial burden and expense" and inadvertent loss of copyright ${ }^{40}$ that had historically accompanied the renewal provision and condemned that systein as "[o]ne of the worst features of the present copyright law." 41

Congress' substitution of a unitary term of protection did not inean that it felt any less obliged to protect authors froin improvident barganis. The purpose of the renewal term was preserved in the termination provisions of the 1976 Act, ${ }^{42}$ which permit authors or their successors in interest $^{43}$ to terminate a prior copyright transfer or license and thereby recapture rights barganied away when their economic value was untested. As the House Report states:

[The termination-of-transfer provisions] are based on the premise that the reversionary provisions of the present section on copyright renewal (17 U.S.C. § 24) should be eliminated, and that the proposed law should substitute for them a provision safeguarding authors against unremunerative transfers. A provision of this sort is needed because of the unequal bargaining position of authors, resulting in part from the impossibility of determining a work's value until it has been exploited. ${ }^{44}$

37. Miller Music, 362 U.S. at 378. The dissent noted that the Court's holding would permit an author with no spouse or children to transfer his or her interest in the renewal term for a valuable consideration, and then renege on that grant by making a testamentary gift of the renewal term to others. Id. (Harlan, J., dissenting).

38. 1976 Act, 17 U.S.C. $\S 302$ (1988).

39. 1976 HOUSE REPORT, supra note 16, at 134-35.

40. Professor Brown notes from the cases that movieinakers in particular have been "extraordinarily careless" about renewing their copyrights, and suggests that this indifference might reflect the industry's forward-looking fixation on the next blockbuster at the expense of concern for its past. Ralph S. Brown, The Widening Gyre: Are Derivative Works Getting Out of Hand?, 3 Cardozo ARTS \& ENT. L.J. 1, 10 (1984).

41. 1976 House REPORT, supra note 16, at 134.

42. 1976 Act, 17 U.S.C. $\S \S 203,304$ (c) (1988).

43. If the author is deceased, the termination right may be exercised by the person or persons who own inore than one-half of the author's termination interest; the formula for division of the termination interest is provided in the applicable sections of the Act. Id.

44. 1976 House RePORT, supra note 16, at 124; see Mills Music, Inc. v. Snyder, 469 U.S. 153, $172-73$ (1985) ("[T]he termination right was expressly intended to relieve authors of the 
The termination right was expressly made inalienable, ${ }^{45}$ presumably in an effort to avoid the sort of judicial dilution that occurred in Fred Fisher. ${ }^{46}$

Congress limited this right in two significant ways, both of which accommodate the competing interests of the author and the grantee. First, grants inade under the Act may be terminated only during a fiveyear period beginning at the end of thirty-five years from the date of the grant. ${ }^{47}$ This period was a coinpromise designed to be long enough to permit grantees to realize a reasonable return on their investinents, but not so long as to allow thein to reap windfalls at authors' expense. ${ }^{48} \mathrm{Sec}$ ond, Congress provided a limited exception for derivative works:

A derivative work prepared under authority of the grant before its termination inay continue to be utilized under the terms of the grant after its termination, but this privilege does not extend to the preparation after the termination of other derivative works based upon the copyrighted work covered by the terminated grant. ${ }^{49}$

Thus, a film inade froin a play or novel may continue to be exhibited after the grant of motion picture rights has been terminated, but its proprietor cannot create any reinakes or sequels. ${ }^{50}$

\section{c. The Nightmare Continues: Renewal in the 1976 Act}

In spite of its dissatisfaction with the renewal system, Congress elected in the 1976 Act to provide for a gradual phaseout of the two-tern structure rather than its coinplete elimination. Thus, the terin of life plus fifty years apphes only to works created on or after January 1, 1978, the effectivc date of the 1976 Act. $^{51}$ For subsisting copyrights, the renewal

consequences of ill-advised and unremunerative grants that had been made before the author had a fair opportunity to appreciate the true value of his work product.").

45. 1976 Act, 17 U.S.C. $\$ 203$ (a)(5) (1988).

46. Mills Music, 469 U.S. at 185-86 (White, J., dissentimg); see supra text accompanying notes 29-32.

47. 1976 Act, 17 U.S.C. $\$ 203$ (1988). If the grant covers the right of publication, the termination period begins at the earhier of thirty-five years from the date of publication or forty years from the date of the grant. Id. $\$ 203$ (a)(3). This tune period apphes only to grants made after the Act's effective date of January 1, 1978. Because the 1976 Act extended the term of protection for subsisting works from fifty-six to seventy-ive years, the same termination right was given for grants made prior to the effective date: such grants could be terminated within a five-year period beginning on the later of the effective date of the Act or fifty-six years after the grant. Id. $\S 304(\mathrm{c})$. The derivative-works exceptions in both situations are identical.

48. Civil and Criminal Enforcement of the Copyright Laws: Hearing Before the Subcomm. on Patents, Copyrights and Trademarks of the Senate Comm. on the Judiciary, 99th Cong., 1st Sess. 86 (1985) (statement of Barbara Ringer, former Register of Copyrights and author of the termination provisions of the $1976 \mathrm{Act}$ ).

49. 1976 Act, 17 U.S.C. $\$ 203(b)(1)$ (1988).

50. 1976 House REPORT, supra note 16, at 127; see Francis M. Nevins, Jr., The Doctrine of Copyright Ambush: Limitations on the Free Use of Public Domain Derivative Works, 25 ST. LouIS U. L.J. 58, 64-65 (1981).

51. 1976 Act, 17 U.S.C. § 302(a) (1988). 
provisions of the 1909 Act were carried over into the 1976 Act, with some modifications. The copyright term for works in their renewal term as of January 1,1978, was extended to seventy-five years from the date of the original copyright, nineteen years longer than the maximum fifty-sixyear term under the 1909 Act. $^{52}$ Similarly, for works still in their initial term on that date, the renewal term was increased to forty-seven years (for a total term of protection of seventy-five years)..$^{53}$

To avoid giving existing copyright grantees a windfall froin the extended renewal term ${ }^{54}$ Congress included a termination provision entitling the copyright owner to terminate any pre-1978 transfers during a five-year period beginning at the end of fifty-six years from the date of copyright (that is, at the beginning of the nineteen-year extension). ${ }^{55}$ Congress also inserted a derivative-works exception, which is virtually identical to that provided for the thirty-five-year termination right. ${ }^{56}$

The derivative-works exceptions of the 1976 Act, like much of the copyright law in general, reflect a legislative comproinise between coinpeting interests-here, (1) the rights of authors and their families, and (2) concern with protecting proprietors of derivative works. ${ }^{57}$ Although some courts had been sensitive to these interests even in construing the 1909 Act, which contained no derivative-works exception, ${ }^{58}$ the lack of an exphicit accommodation of the coinpeting rights in the earher statute set the scene for a decision with potentially severe consequences for the public interest. $^{59}$

52. Id. § 304(b).

53. Id. § 304(a).

54. 1976 HouSE REPORT, supra note 16, at 140 ("[T] he extended [renewal] term represents a completely new property right, and there are strong reasons for giving the author, who is the fundamental beneficiary of copyright under the Constitution, an opportunity to share in it.").

55. 1976 Act, 17 U.S.C. $§ 304(c)$ (1988). If the fifty-six-year term expired before January 1 , 1978 , the termination period began instead on the Act's effective date. Id. This situation could arise becanse Congress had anticipated the general revision legislation by extending all renewal terms scheduled to expire between September 19, 1962, and December 31, 1976, to the latter date. 1976 HOUSE REPORT, supra note 16, at 134 n.1.

56. 1976 Act, 17 U.S.C. $\$ 304($ c)(6)(A) (1988); see supra text accoinpanying notes 49-50.

57. See 1976 HOUSE REPORT, supra note 16, at 124 ("Section 203 reflects a practical compromise that will further the objectives of the copyright law while recognizing the problems and legitimate needs of all interests involved."); REGISTER OF COPYRIGHTS, 89TH CONG., 1sT SESS., Supplementary Report on the General Revision of THE U.S. Copyright LAW: 1965 Revision BILl 72 (H.R. Judiciary Comm. Print 1965) [hereinafter SUPPLEMENTARY REPORT OF THE REGISTER OF COPYRIGHTS] ("[W]e have sought actively and persistently to find a basis for agreement that would be of practical benefit to authors and their families without being unfair to publishers, film producers, and other users.").

58. Carol A. Ellingson, The Copyright Exception for Derivative Works and the Scope of Utilization, 56 IND. L.J. 1, 5 (1980).

59. A detailed study of the history and workings of the termination-of-transfer provisions and the derivative-works exception is beyond the scope of this Comment. For more comprehensive analyses, see generally Jeffrey A. Cohen, Derivative Works Under the Termination Provisions in the 


\section{B. The Rights of the Derivative-Work Owner: Subordination and New-Property-Right Theories}

As discussed above, the 1976 Act is significantly more successful than the 1909 Act, both in defining the scope of protection for derivative works and in protecting those works, once created and copyrighted, from the control of the underlying-copyright proprietor. The provisions of the 1909 Act are ambiguous concerning the right of the author of an underlying work to control the continued distribution of a derivative work after the rights to the underlying material have reverted. This ambiguity gave rise to two distinct judicial interpretations that provided different answers to the question ultimately decided by the Supreme Court in Stewart: whether the death of an author of an underlying work during the work's initial copyright term leaves the owners of a duly authorized and copyrighted derivative work at the inercy of the author's statutory successors with regard to the right to contmue exploiting the derivative work during the underlying work's renewal term.

\section{The Subordination Theory}

One line of cases decided under the 1909 Act held that a derivativework owner could not continue to exploit that work after the loss of rights to the underlying work-that is, the derivative owner's rights were subordinate to those of the underlying-copyright owner. ${ }^{60}$ Fitch $v$. Shubert, ${ }^{61}$ the first case to address the issue, stated in dicta that the proprietor of a derivative work inust have a hicense froin the proprietor of the underlying work in order to continue exploiting the derivative work during the underlying work's renewal term.

G. Ricordi \& Co. v. Paramount Pictures ${ }^{62}$ is often used to support

1976 Copyright Act, 28 BULL. COPYRIGHT SOC'Y U.S.A. 380, 383-92 (1980); Ellingson, supra note 58, at 7-11; Mimms, supra note 36, at 596-602, 621-34; Melville B. Nimmer, Termination of Transfers Under the Copyright Act of 1976, 125 U. PA. L. REv. 947 (1977).

60. The subordination theory was the creation of Professor Nimmer, who maintained that all interests in a derivative work are secondary when they conflict with copyright interests in an underlying work. See 1 NIMMER \& NIMMER, supra note 15, § 3.07[A][1], at 3-32. The theory lias beeu supported by several other commentators. See, e.g., Bricker, supra note 23, at 43; Mimms, supra note 36, at 615-17; Barbara A. Ringer, Renewal of Copyright, in 1 STUDIES ON COPYRIGHT 503, 562-63 (Arthur Fisher inem. ed. 1963) (study no. 31).

61. 20 F. Supp. 314 (S.D.N.Y. 1937). The plaintiff was the statutory successor to the copyright in a play that had been licensed during its initial term to the defendant for the production of an operetta. The initial license agreement was linited to the first term. After securing the renewal term in the underlying play and hicensing the defendant's continued exploitation of the operetta, the plaintiff sued for infringeinent of the play. The court found no infringeinent because of the valid hicense granted by the plaintiff, but expressed its belief that such a license was required to allow the defendant to continue exploitation of the derivative work after renewal of the copyriglit in the underlying work. The court stated that upon renewal of the underlying work's copyriglit, its proprietor "acquired a new and independent right in the copyright, free and clear of any riglits, interests, or lieenses attached to the copyright for the initial term." Id. at 315.

62. 189 F.2d 469 (2d Cir.), cert. denied, 342 U.S. 849 (1951). 
the subordination theory, ${ }^{63}$ but the case actually dealt with the right of a derivative-work owner to hicense a further derivative work during the renewal term without obtaining renewal rights from the original author's statutory successors. In Ricordi, John Luther Long, author of the novel Madame Butterfly, had granted a hicense to David Belasco to produce a play version. Long and Belasco subsequently granted exclusive rights to Ricordi to write a libretto for an opera of the play. ${ }^{64}$ The result was the classic Puccini opera, which was copyrighted by Ricordi. When Paramount Pictures obtained motion picture rights in the novel and the play, Ricordi brought suit for a declaratory judginent that he was the exclusive owner of the motion picture rights in the opera.

The Second Circuit held that Ricordi's copyright in the operatic version was limited to the new matter that had been added to the novel and play and that he could not make general use of the underlying novel for a film version. ${ }^{65}$ The opinion can be read to suggest that Ricordi lost the right to exploit the underlying material as embodied in the opera following the expiration of the initial copyright term, even though the opera was created under a valid hicense from the underlying-copyright owners. It is more accurately interpreted, however, as merely denying Ricordi the right to authorize a second-generation derivative work (that is, a new work using an existing derivative work as its underlying source). ${ }^{66}$

Perhaps the strongest illustration of the bite of the subordination theory occurs if the copyright is renewed on an underlying work but not on its corresponding derivative work. Professor Nevins refers to this condition as "copyright ambush" because although the derivative work is technically in the public domam, the public is not free to exploit it. ${ }^{67}$ For example, in Filmvideo Releasing Corp. v. Hastings (the Hopalong Cassidy case $^{68}$ the Second Circuit held that failure to renew the copyright in derivative movies does not send the underlying works into the public domam; therefore, broadcasting the films during the underlying works' renewal terms without the permission of the underlying works' proprietor would constitute copyright infrimgement. ${ }^{69}$ Noting that "a derivative

63. See, e.g., 1 NIMMER \& NIMMER, supra note 15, § 3.07[A], at 3-33.

64. As in Fitch, the licensing agrcements did not purport to run beyond the initial term of copyright in the underlying works.

65. Ricordi, 189 F.2d at 471.

66. See Ellingson, supra note 58, at 14-15; Donald S. Engel, Importation and Protection of Works of American Authors Manufactured Abroad via the U.C.C. Exemption from Formalities: How Now Sacred Cow?, 12 Bull. COPYRIGHT Soc'y U.S.A. 83, 119 n.126 (1964); see also Mills Music, Inc. v. Snyder, 469 U.S. 153, 183 n.7 (White, J., dissenting) (discussing broad and narrow interpretations of Ricordi).

67. Nevins, supra note 50 , at 65 . Nevins points out that "there may be hidden patches of copyright in certain public domain works, subjecting those who exploit such works to unanticipated liability for infrimgeinent of the copyright in the source work." Id.

68. 668 F.2d 91 (2d Cir. 1981).

69. Id. at 92-93. The court may have been infiuenced by the fact that the original license to 
copyright is a good copyright only with regard to the original embellishments and additions it has made in the underlying work," held that "[s]ince the proprietor of a derivative work cannot convey away that which he does not own ... it follows that he cannot release that which he does not own into the public domain."71

The Ninth Circuit reached the same result in Russell v. Price. ${ }^{72}$ Copyright in a film based on George Bernard Shaw's Pygmalion had not been renewed but Shaw's copyright in the play had been, and his successors brought suit to enjom the unlicensed distribution of the film. The court held that the underlying play's copyright protection barred its unlicensed use even as incorporated into the public-domain derivative film, stating that "although the derivative work may enter the public domain, the inatter contained therein which derives from a work still covered by statutory copyright is not dedicated to the public."73

\section{The New-Property-Right Theory}

In contrast to the subordination theory, the new-property-right theory postnlates that once a derivative work is validly prepared, a new property right springs into existence and the proprietor of the derivative work inay contimue to make use of the underlying work as already einbodied in the derivative work after the termination or reversion of rights to the underlying material. ${ }^{74}$ Although this theory was repudiated by the Supreme Court's Stewart decision, it had previously garnered the support of such distimguished jurists and commentators as Judge Friendly $^{75}$ and Professors Ellingson, Jaszi, and Nevins. ${ }^{76}$

Filmvideo's predecessor in interest specifically reserved television, broadcasting, and radio rights in Hastings' predecessor. Id. at 92.

70. $I d$.

71. Id. at 93; accord Grove Press, Inc. v. Greenleaf Publishing Co., 247 F. Supp. 518, 526-27 (E.D.N.Y. 1965) (holding that copying of public-domain English translation of Jean Genet's The Thief's Journal infringed Genet's copyriglit in the French text).

72. 612 F.2d 1123 (9th Cir. 1979), cert. denied, 446 U.S. 952 (1980).

73. 'Id. at 1128. The court cited Nimmer for "the well-established doctrine that a derivative copyriglit proteets only the new material contained in the derivative work, not the matter derived froin the underlying work." Id. (footnote omitted). For further analysis of the Russell decision, see Daniel C. Moyles, Note, Russell v. Price: A Limitation on the Use of Derivative Works, 11 GoldEN GATE U. L. REv. 323 (1981). For an expression of the subordination theory under principles of contract rather than copyright law, sec Gilliain v. American Broadcasting Cos., 538 F.2d 14 (2d Cir. 1976).

74. See 1 NIMMER \& NiMMER, supra note 15, § 3.07[A], at 3-32.

75. See Rohauer v. Killianı Shows, Inc., 551 F.2d 484 (2d Cir.), cert. denied, 431 U.S. 949 (1977).

76. See Ellingson, supra note 58; Peter Jaszi, When Works Collide: Derivative Motion Pictures, Underlying Rights, and the Public Interest, 28 UCLA L. REv. 715 (1981); Nevins, supra note 50. Of course, the theory lias been criticized by subordination proponents as contrary to the basic protectionist principle of the 1909 Act. See, e.g., 1 NimMER \& Nimmer, supra note 15, § 3.07[A], at 3-32 (arguing that new-property-right theory "is neither warranted by any express provision of the 
The new-property-right theory made its first modern appearance in Edmonds v. Stern. ${ }^{77}$ In that case a composer who held the copyright in a song sued another composer who, with the first composer's consent, had used the song in an operetta and copyrighted a derivative orchestral medley of the operetta music. The Second Circuit held that the plaintiff's copyright in the underlying song "had no effect whatever on the copyright of the operatic score theretofore taken out."78 Once the plaintiff consented to the mcorporation of his song in the orchestral medley, "a right of property sprang imto existence, not at all affected by the conveyance of any other right."79 Thus, although the rights to the underlying material had been lost, the court permitted the contimued exploitation of the derivative work.

In 1977 the Second Circuit decisively espoused the new-propertyright theory in Rohauer v. Killiam Shows. ${ }^{80}$ On facts virtually identical to those of Stewart, Rohauer held that the owner of a derivative motion picture copyrighted under the 1909 Act could continue to distribute the motion picture during the renewal term of the underlying hiterary work notwithstanding the death of the underlying work's author before her renewal rights vested and could be transferred to the derivative-work owner. The decision's clear resolution of the section 7-section 24 conflict in favor of the derivative-work owner provided a precedent on which Hollywood studios retied for over a decade by exploiting derivative works without regard to securing rights for the renewal term in the underlying works. 81

In Rohauer the author of a novel granted motion picture rights to the defendant's predecessors $m$ interest and agreed to renew the novel's copyright at the appropriate time and to assign the renewal to the purchaser. The motion picture-the classic Rudolph Valentino silent, Son of the Sheik - was copyrighted as a derivative work under section 7, and the copyright was renewed twenty-eight years later. The novel's author died, however, before the renewal term of the novel's copyright vested. Her daughter subsequently obtained the renewal under section 24 and granted exclusive motion picture and television rights in the novel to the

[1909] Copyright Act, nor by the rationale as to the scope of protection achieved in a derivative work" (footnote omitted)).

77. 248 F. 897 (2d Cir. 1918). For an elaboration of the pre-1909 traces of the theory in English and American copyright law, see Jaszi, supra note 76, at $780-86$.

78. Edmonds, 248 F. at 898.

79. Id.

80. 551 F.2d 484 (2d Cir.), cert. denied, 431 U.S. 949 (1977).

81. The ultimately infringing rerelease of Rear Window was apparently made in reliance on Rohauer. Stewart v. Abend, 110 S. Ct. 1750, 1756 (1990). Hollywood's continued dependence on the decision was of questionable prudence given the Ninth Circuit's skeptical reading of Rohauer two years later in Russell v. Price, 612 F.2d 1123, 1127 n.13, 1128 n.16 (9th Cir. 1979), cert. denied, 446 U.S. 952 (1980). 
plaintiff, Rohauer. When the defendant provided a print of the film for television broadcast without a hcense from Rohauer, the plaintiff sued for infringement of the underlying novel's copyright. The defendant argued that although no new movie version could be made during the novel's renewal tern, the original grant entitled the defendant to contimue exploiting the film irrespective of the author's death and the corresponding shift of the novel's copyright to her statutory successor. Judge Friendly stated that the case presented "a question of copyright law of first impression" that required the court "to ascertain what would have been the thought of the 1909 Congress on an issue about which it almost certainly never thought at all." $\$ 2$

The court dismissed the "force or validity" clause of section 7 as irrelevant, finding that, in light of its legislative history, the clause's liunitations were imtended ouly to ensure that nothing done by the proprietor of the derivative copyright could impair or extend the duration of the underlying copyright or give the derivative proprietor an exclusive right to the underlying work. ${ }^{83}$ The clause did not deny the derivative owner a nonexclusive right to use the underlying work to the cxtent incorporated im the new work under a valid grant made during the underlying work's original copyright terin. Although the author's statutory successors retained the exclusive right to use or hcense the use of the underlying work for new derivative works, ${ }^{84}$ this did not affect the property right in an existing derivative work that had been prepared with the consent of the author and was protected by its own section 7 copyright. ${ }^{85}$ The court exphicitly rejected the ideas that the copyright im a derivativc work protects only the "new matter" contained therein and that a statutory successor obtains an unencumbered "new estate" im the underlying copyright. ${ }^{86}$

Finding no precedent on point, the court turned to pohicy considerations and found that "the equities he preponderantly in favor of the proprietor of the derivative copyright." 87 The court acknowledged that "a person who with the consent of the author has created an opera or a motion picture film will often have made contributions literary, musical

\footnotetext{
82. Rohauer, 551 F.2d at $485-86$.

83. Id. at $488-90$.

84. Id. at 493.

85. Id. at 492 .

86. Id. Fitch and Ricordi were distinguished because the license agreements in those cases did not purport to extend beyond the initial term. Id. at 490-91. The Supreme Court's Fred Fisher and Miller Music decisions were distinguished as concerning only the competing demands of persons claiming full ownership of an underlying copyright's renewal term rather than the proper reconciliation betwcen copyrights in two works under $\$ \S 7$ and 24 and the extent of control that an underlying author is entitled to impose over the owner of a licensed derivative work. Id. at 490.

87. Id. at 493.
} 
and economic, as great as or greater than the original author." ${ }^{88}$ Furthermore, purchasers of derivative rights have no effective way to protect themselves against the author's death before the renewal period, ${ }^{89}$ whereas underlying authors can always protect their heirs through contractual limitations on the assignment. ${ }^{90}$ The court supported these policy considerations by citing the derivative-works exception to the termination-of-transfer provisions in the 1976 Act as "evidence of a behef on the part of Congress of the need for special protection for derivative works." 91

The Rohauer decision engendered strong reactions from both sides of the scholarly debate, ${ }^{92}$ and the Ninth Circuit characterized Judge Friendly's distinction of Ricordi as "unconvincing."93 In fairness to the subordination theorists, this particular criticism was on the mark. The Rohauer court distinguished such classic subordination cases as Fitch and Ricordi by observing that the hicensing agreements in those cases did not purport to run beyond the first term. If the creation of a derivative work truly generates a new property right, however, then the mention or nonmention of renewal rights in the origuial agreement should be inconsequential (absent an exphicit contractual limitation of rights ${ }^{94}$ ). Either the derivative work is subordinate to the underlying work, in which case the derivative proprietor is dependent on a grant of rights in the renewal term, or else the derivative work is a "new work" entitled upon creation to full copyright protection, in which case the intent of the grantor regarding the renewal term is irrelevant. Although the Rohauer court mentioned the grantor's intent to convey derivative rights for the renewal

88. Id.

89. See infra text accompanying notes 183-89.

90. Rohauer, 551 F.2d at 493-94.

91. Id. at 494.

92. Compare 1 NiMMER \& NIMMER, supra note $15, \S 3.07$ [A], at 3-40 (stating that Rohauer "is plainly wrong") and Brown, supra note 40, at 19 (criticizing Rohauer as "an aberration, and not a minor one") with Richard Colby, Rohauer Revisited: "Rear Window," Copyright Reversions, Renewals, Terminations, Derivative Works and Fair Use, 13 PEPP. L. REv. 569, $570-71$ (1986) (arguing that the decision was "correct and fully consistent with copyright theory and . . . a rcconfirmation of copyright in derivative works") and Ellingson, supra note 58, at 41 (explaining that Rohauer "may sully the pristine purity of copyright theory, but it definitely reaches a result desirable from the public's viewpoint without inflicting undue harm on authors of underlying works").

93. Russell v. Price, 612 F.2d 1123, 1128 n.16 (9th Cir. 1979), cert. denied, 446 U.S. 952 (1980) ("The 1909 Act inade no distinction between a copyright owner's right to authorize copying or exhibition of the work as it appears in an existing derivative work and the right to authorize creation of a new derivative work.").

94. An explicit coutractual limitatiou of rights to the initial copyright term would require different treatunent. Authors are free to grant only those rights they choose to and may inpose contractual limits on the use of the underlying work in the derivative work during the underlying work's renewal term. See Nevins, supra note 50, at 61 (stating that availability of film for contractually limited term "inay have to be accepted reluctantly as a tragedy without legal recourse in a free society"). 
term, the decision did not turn on that point. Thus, if Rohauer was correct, then Fitch and Ricordi were wrongly decided: although the grants in those cases did not refer to the renewal term, that factor would be immaterial if the derivative works received full copyright protection under the terms of the 1909 Act. ${ }^{95}$

Despite judicial and scholarly questioning, Rohauer provided a precedent on which Hollywood was happy to rely. ${ }^{96}$ It would not be until inore than a decade later, when the Supreine Court decided Stewart $v$. Abend, that Rohauer's accommodation of the competing 1909 provisions would be definitively rejected.

\section{Stewart v. Abend}

In 1942 Cornell Woolrich published a short story entitled It Had to Be Murder in Dime Detective Magazine. ${ }^{97}$ Three years later, Woolrich sold the motion picture rights to several of his stories, including It Had to Be Murder, to B.G. De Sylva Productions. ${ }^{98}$ As part of the sale agreement, Woolrich agreed to renew the copyrights in the stories at the appropriate time and to assign the motion picture rights for the renewal terms to De Sylva. ${ }^{99}$ In 1953 Patron, Inc., a production company formed by Alfred Hitchcock and James Stewart, purchased the inotion picture rights to It Had to Be Murder from De Sylva's successors in imterest for $\$ 10,000 .{ }^{100}$ Patron and Paramount Pictures produced and distributed the motion picture Rear Window, based on It Had to Be Murder and starring James Stewart and Grace Kelly. ${ }^{101}$ The inovie was copyrighted by Patron under section 7 of the 1909 Copyright Act. ${ }^{102}$

Woolrich died in 1968, only months before the time for renewal of

95. Under a strict application of the new-property-right theory, it would appear that Ricordi would lave liad the right not only to continue exploiting Madame Butterfly during the underlying work's renewal term, but also to make thc movie of the opera. His copyright in the opera would have imcluded all of the bundle of rights enumerated in $\$ 1$ of the 1909 Act, including the right to create other versions under $\S 1(\mathrm{~b})$. The argument need not be taken this far, however, for the motion picture would seemingly also constitute a derivative version of the novel and play, the authorization of whicl was within the exclusive rights of Paramount Pictures.

96. David Nimmer, Refracting the Window's Light: Stewart v. Abend in Myth and in Fact, 39 J. CoPYRIGHT Soc'Y U.S.A. 18, 29 (1991).

97. Stewart v. Abend, 110 S. Ct. 1750, 1755 (1990). The magazine's publisher, Popular Publications, Inc., obtained only the right of magazine publication from Woolrich; the author retained all otler riglits in the story. Popular Publications also obtained a blanket copyright for thc issue in wlicli It Had to Be Murder appeared. Id.

98. Id.

99. Id.

100. Id.

101. Abend v. MCA, Inc., 863 F.2d 1465, 1467 (9th Cir. 1988), aff'd, 110 S. Ct. 1750 (1990).

102. Brief for the Petitioners at 5, Stewart v. Abend, $110 \mathrm{~S}$. Ct. 1750 (1990) (No. 88-2102) [hereinafter Petitioners' Brief]. When Patron was dissolved in 1960, the film's copyright was assigned to Hitclicock, Stewart, and their agent, MCA Artists Ltd., predecessor in interest to MCA, Inc. Id. at 8 n.17. 
the story's copyright ${ }^{103}$ and consequently before he could reassign the movie rights to De Sylva. He had no surviving spouse or child, and his property was left to a trust for Columbia University. Chase Manhattan Bank, Woolrich's executor and the administrator of the trust, renewed the copyright in It Had to Be Murder in December 1969 and assigned the renewal rights to a hiterary agent and copyright speculator named Sheldon Abend in exchange for $\$ 650$ plus $10 \%$ of all proceeds from exploitation of the story. ${ }^{104}$

In 1971 Rear Window was broadcast on ABC network television. Abend notified the owners of the movie that he owned the copyright renewal and that their exhibition of the film without his consent constituted infringement of his copyright in the story. Despite this warning, the film's owners (Hitchcock, Stewart, and MCA, Inc.) entered into a second hicense with $\mathrm{ABC}$ to rebroadcast the movie. ${ }^{105}$ Abend promptly filed suit for copyright infringement in the District Court for the Southern District of New York. ${ }^{106}$ The litigation was later settled for $\$ 25,000^{107}$ and the inovie was withdrawn from the viewing public. ${ }^{108}$

In 1977 the Second Circuit decided Rohauer v. Killiam Shows, ${ }^{109}$ holding that a derivative work's independent copyright permitted continued exhibition without infringement after the lapse of rights in the underlying work. ${ }^{110}$ Relying on that decision, the owners of Rear Window authorized Universal Pictures to rerelease the film in theaters, on cable television, and on videocassettes and videodiscs. ${ }^{111}$ The rerelease generated over $\$ 12$ million in revenue. ${ }^{112}$ Abend agam filed suit, this time in the District Court for the Central District of California against Hitchcock's estate, Stewart, MCA, and Universal Film Exchanges (an MCA subsidiary and the film's distributor). The complaint alleged that the rerelease infringed Abend's copyright in It Had to Be Murder and interfered with his ability to produce other derivative works based on the

103. Under $\S 24$ of the 1909 Act, application for the renewal term must be made to the copyright office within one year prior to the expiration of the original term. 1909 Act, 17 U.S.C. $\S 24$ (1976) (originally enacted as Act of Mar. 4, 1909, ch. 320, § 23, 35 Stat. 1075, 1080). Because It Had to Be Murder was originally copyrighted by the publisher of Dime Detective Magazine in February 1942, Woolrich would have been eligible to apply for the renewal term in February 1969.

104. Stewart, $110 \mathrm{~S}$. Ct. at 1755-56.

105. Id. at $\mathbf{1 7 5 6 .}$

106. Abend v. American Broadcasting Co., Civ. No. 74-2336 (S.D.N.Y. filed May 30, 1974), cited in Francis M. Nevins, Jr., Rx for Copyright Death, 1977 WASH. U. L.Q. 601, 602 n.9.

107. Stewart, $110 \mathrm{~S}$. Ct. at 1756 . This settlement seems to confirm the view that the later Rohauer opinion represented a break with prevailing law. Nimmer, supra note 96 , at 29 n.50.

108. See Nevins, supra note 106, at 602 n.9.

109. 551 F.2d 484 (2d Cir.), cert. denied, 431 U.S. 949 (1977).

110. See supra notes $80-91$ and accompanying text.

111. Stewart, $110 \mathrm{~S}$. Ct. at 1756.

112. Abend v. MCA, Inc., 863 F.2d 1465, 1468 (9th Cir. 1988), aff'd, 110 S. Ct. 1750 (1990). 
story. 113

The district court denied Abend's motion for summary judgment as to copyright infringenient and also denied the defendants' sunimary judgment motion based on alleged defects in the story's copyright. ${ }^{114}$ However, the court granted the defendants' motions for summary judgment based on Rohauer and the "fair use" defense. 115 In an opinion by Judge Harry Pregerson, the Court of Appeals for the Nimth Circuit reversed, holding that the continued exploitation of Rear Window without a valid grant of rights in the underlying story's renewal tern infringed Abend's copyright in It Had to Be Murder. ${ }^{116}$ The United States Suprenie Court, by a six to three vote, affirmed the Ninth Circuit's decision in an opinion written by Justice O'Counor.

The Court began by noting the long history of the two-term copyright systen 1 and the pohcies behind the renewal provision: givmg the author a second chance to benefit froin his work's success and ensuring security for his family in the event of the author's death. ${ }^{117}$ Relying on Miller Music's holding that an author's assignment of a renewal copyright in toto during the initial term is invalid if the author dies before the renewal period, ${ }^{118}$ the Court reasoned that an in futuro assignnient of any portion of the renewal rights, such as the right to produce a derivative work, is also contingent upon the rights subsequently vesting in the assignor. ${ }^{119}$ Therefore, because Woolrich died before the renewal tern,

113. Stewart, $110 \mathrm{~S}$. Ct. at 1756. Specifically, Abend alleged that defendants interfered with his attempts to contract with Home Box Office (HBO) for a television version of the story by writing to HBO and stating that neither Abend nor HBO could use the titles Rear Window or It Had to Be Murder. Id.

114. Id. at 1756-57.

115. Id. at 1756. The "fair use" defense was rejected by both the Ninth Circuit and the Supreme Court. See Abend, 863 F.2d at 1480-82; Stewart, 110 S. Ct. at 1768-69. It is my opinion that the summary judgment on this ground was correctly reversed on appeal. The "fair use" argument, however, is not relevant to the purposes of this Comment or to Stewart's significance and will therefore be ignored.

116. Abend, 863 F.2d 1465. Judge Pregerson's opimion relied on virtually the same analysis as Justice O'Counor's and need not be discussed here at length. For a more comprehensive analysis of the Ninth Circuit's opinion, sec Barbara A. Allen \& Susan R. Swift, Shattering Copyright Law: Will James Stewart's Rear Window Become a Pane in the Glass?, 22 PAC. L.J. 1, 27-30 (1990); Todd G. Scher, Note, Copyright Protection: The Erosion of Renewal Rights Under the Copyright Act of 1909, 7 ENT. \& Sports L. Rev. 167 (1989); Peter J. Settle, Note, Underlying Copyright Renewal and Derivative Works: Abend v. MCA, Inc., 58 U. CIN. L. REV. 1069, 1083-95 (1990); Laura T. Stine, Note, Classic Motion Pictures Based on Copyrighted Stories-Ninth Circuit Leaves Legacy of Confusion: Abend v. MCA, Inc., 63 ST. JoHN's L. REv. 629 (1989).

117. Stewart, $110 \mathrm{~S}$. CI. at 1758-59.

118. See supra notes $34-37$ and accoinpanying text.

119. Stewart, $110 \mathrm{~S}$. Cl. at 1760 . The Court did not address the question of "whether the renewal rights vest upon commencement of the registration period, registration, or the date on which the original term expires and the renewal term begins." Id. at 1759 n.2. This issue was also not addressed in Fred Fisher or Miller Music, and the treatment of the case of an author who dies during the last year of the initial term (either before or after filing for the renewal) remains unclear. The only gnidance currently available is found in Frederick Music Co. v. Sickler, 708 F. Supp. 587 
the Court concluded that the assignees were left with "an unfulfilled expectancy." 120

The Court went on to dismiss Rohauer as "creat[ing] an exception to our ruling in Miller Music and . . . an 'intrusion' on the statutorily created rights of the owner of the pre-existing work in the renewal tern." 121 Reaffirming the Russell $v$. Price doctrine that the copyright in a derivative work protects only the new inaterial contained therein, ${ }^{122}$ the Court stated that the plain language of the section 7 "force or validity" clause makes clear that any underlying material incorporated in a derivative work "remains on grant from the owner of the pre-existing work." 123 The fact that the two works miglit be inseparably intertwined was dismissed as "irrelevant." 124

The Court also rejected the argument that the 1976 derivative-works exception evidenced congressional intent to prevent underlying-work proprietors froin blocking distribution of derivative works. The Court believed that the series of compromises that led to the exception precluded the drawing of a clear policy behind the section ${ }^{125}$ and, furtliermore, that Congress would not have bothered to include the exception unless it believed that the underlying proprietor wonld otherwise possess the right to sue the derivative proprietor for infringement. ${ }^{126}$

Finally, the Court addressed the pohicy concern urged by petitioners that the Ninth Circuit's rule would inhibit the dissemination of works to the public. While stating tliat "[ $t]$ hese arguinents are better addressed by Congress than the courts," 127 . the Court noted that the limited inonopoly already balances the desire to provide a fair return to authors with the need to maintain public access to creative works. ${ }^{128}$ Returning to the "second chance" rationale of the renewal provision, the Court found that the circumstance under which the petitioners would have to pay more for the derivative rights than they had expected "was contemplated by Con-

(S.D.N.Y. 1989), in which one of the authors of a song died during the twenty-eighth year of the original copyright term, after registering for renewal but before the commenceinent of the renewal term. The court, characterizing the issue as one of first impression, held that the renewal right vests upon registration for renewal during the author's lifetime and within the statutorily prescribed renewal period. The court found no justification for requiring the author's survival into the actual renewal term. Id. at 589-92.

120. Stewart, $110 \mathrm{~S}$. Ct. at 1760.

121. Id. at 1761 (quoting Petitioner's Brief, supra note 102, at 33). Strangely, the Court did not actually overrule Rohauer, and stated that the rule in that case "might inake some sense in some contexts." Id. at 1763.

122. See supra notes $72-73$ and accompanying text.

123. Stewart, $110 \mathrm{~S}$. Ct. at 1761.

124. Id.

125. Id. at $1762-63$.

126. Id. at 1763.

127. Id. at 1764 .

128. Id. 
gress and is consistent with the goals of the Copyright Act."129 In conclusion, the Court held that

the grant of rights in the pre-existing work lapsed and, therefore, the derivative-work owner's rights to use those portions of the pre-existing work incorporated into the derivative work expired. Thus, continued use would be infringing .... To say otherwise is to say that the derivative work nullifies the "force" of the copyright in the "Inatter einployed." Whether or not we believe this is good policy, this is the systein Congress has provided, as evidenced by the language of the 1909 Act and the cases decided under the 1909 Act. $^{130}$

Although a comprehensive analysis of the Court's legal reasoning is beyond the scope of this Comment, ${ }^{131}$ which will focus imstead on arguing the failure of the decision from a pohicy perspective and on appealing for remedial congressional action, two poimts bear emphasizing.

First, although the Court stated that its decision was controlled by Miller Music, Rohauer provided a valid basis for distinguishing that case, ${ }^{132}$ and a different result in Stewart would not have been inconsistent with it. Miller Music stands for the proposition that because authors cannot sell more than they own, they cannot convey the renewal term in advance. This holding is consistent with both the plain language of section 24 and the pohicy behind the renewal systein. All this means, however, is that authors cannot convey in advance the second-term rights to print, copy, or create derivative works from their underlymg work. That was not the issue in Stewart, which instead concerned whether Woolrich's death before the renewal term nullified the independent copyright in the existing derivative work.

The argument that an author cannot assign in advance the right to continue exploiting derivative works hicensed in the first term is necessarily circular because it presupposes that the derivative-work proprietor would be dependent on such an assignment-the very contention rejected by proponents of the new-property-right theory. The Court's reasoning - that because the full renewal term can ouly be assigued as an expectancy, an im futuro assignment of the right to produce a derivative work must be treated the saine way-is technically correct but adds nothing to the argument because it assumes for its relevance that such an assignment is necessary not only to create new derivative works but also

129. Id.

130. Id. at 1768.

131. Such analysis is adequately provided elsewhere. The majority opinions of the Ninth Circuit and Supreme Court are comprehensively criticized in the respective dissents of Judge Thompson, Abend v. MCA, Inc., 863 F.2d 1465, 1483 (9th Cir. 1988), aff'd, 110 S. Ct. 1750 (1990), and Justice Stevens, Stewart, $110 \mathrm{~S}$. Ct. at 1769. For further critiques of the Ninth Circuit's analysis, see sources cited supra note 116.

132. See supra note 86. 
to continue exploiting existing ones. ${ }^{133}$

Second, the "force or validity" clause of section 7 does not clearly compel the Court's holding. Although the Court's reading of section 7 is defensible, an equally tenable interpretation is that a derivative work can be fully protected without diluting or extending the copyright in the underlying material. The copyright in the underlying work remains secure: its proprietor remains free to hicense all rights not previously granted, including the right to prepare other derivative works, and proprietors of derivative works are liable for infringement if they use the underlying inaterial for any purpose other than that for which they have specifically bargained. To say, as section 7 does, that the derivative work shall not give its proprietor "an exclusive right" to use the underlying work does not mean that the derivative owner shall have no right at all. As Justice Stevens pointed out, the very language of the clause suggests by negative imphication that it does leave the derivative-work proprietor with a nonexclusive right to use the original work as embodied in the derivative work. ${ }^{134}$

As the foregoing discussion and the continuing debate illustrate, there are at least two reasonable ways of reading the relevant provisions of the 1909 Copyright Act. Unfortunately, the legislative history sheds hittle hight on the proper resolution because, as the Rohauer court pointed out, the problem at hand is one "about which [the 1909 Congress] almost certainly never thought at all."135 Adding to the complexity is the fact that the statute has now been superseded by the provisions of the 1976 Act, which incorporated much of the 1909 Act's ainbiguity in the carryover of the renewal systein for certain works. ${ }^{136}$ As the next Part of this Comment will argue, strong pohicy concerns and potential harm to the public welfare may nonetheless impel Congress to correct the Supreme Court's precarious balancing of interests.

133. See Studios' Amicus Brief, supra note 4, at 26 n.35:

The rule that an author's death before renewal terminates his assignee's contractual right to produce new derivative works during the renewal term simply has no relevance to the issue whether the author's death before renewal nullifies section 7's statutory grant of rights to derivative works that are both created with the author's consent during the original term and distributed thereafter in strict conformance with the terms of that consent.

134. Stewart, $110 \mathrm{~S}$. Ct. at 1771 (Stevens, J., dissenting).

135. Rohauer v. Killiam Shows, Inc., 551 F.2d 484, 486 (2d Cir.), cert. denied, 431 U.S. 949 (1977).

136. See supra notes 51-56 and accompanying text. 
II

Shards of Glass: Policy IMPlications of STEWART

\author{
"What is it you want, a lot of money?" \\ Murder suspect Raymond Burr confronting \\ James Stewart in Rear Window ${ }^{137}$
}

In the immediate aftermath of the Ninth Circuit and Supreme Court Rear Window decisions, motion picture industry insiders expressed opposing viewpoints on the probable consequences. While one studio executive expressed his behief that the "likely effect" would be to foreclose distribution of numerous films, ${ }^{138}$ the head of litigation for another major studio stated that there would be "no significant impact" and called the Stewart decision "a disappointment, but no surprise."139 Some industry observers predicted an " "avalanche of lawsuits" "and " "fewer [available] movie classics," "140 while one intellectual property practitioner criticized the "Chicken Little" reaction of the imdustry. ${ }^{141}$ A Loyola Law School copyright professor announced that the decision "fundamentally alters the way business must be done in the entertainment imdustry," 142 while a colleague at Harvard Law School opined that "[t]he studios are just crying in their beer." 143 Interviews with several entertainment lawyers and studio sources suggest that the pessimistic view has proved the more accurate. ${ }^{144}$

This Part explores two broad categories that embody most of the significant policy problems with Stewart. First, the decision generates effects that are inconsistent with the established goals of copyright legislation by failing to give derivative works adequate protection. Second, the decision creates imequities by subordinating the rights of derivativework creators-who have often made significant economic and artistic contributions to the work- to the financial deinands of authors and stat-

137. REAR WINDOW (Paramount 1954).

138. Bruce Eder, 'Rear Window' Case Chills Film Industry, NewsdaY, Jan. 14, 1989, Part II, at 7 (Nassau \& Suffolk ed.).

139. Gail D. Cox, View Through 'Rear Window' Looks Less Dire, NAT’L L.J., May 14, 1990, at 24.

140. Nimmer, supra note 96, at 28-29 (quoting Associated Press, Apr. 25, 1990, Wed., AM cycle).

141. Francis G. Rushford, Stewart v. Abend: The Last Picture Show?, NEw MatTer, Spring 1991, at 3, 13 .

142. Lionel S. Sobel, View from the "Rear Window": A Practical Look at the Consequences of the Supreme Court's Decision in Stewart vs. Abend, ENT. L. REP., June 1990, at 3, 3.

143. Cox, supra note 139 , at 24 .

144. Several sources agreed to be interviewed for this Comment on condition of complete anonymity. This is presumably a result of the fiercely competitive nature of the motion picture industry and, in particular, the studio system. Where "hot" issues such as Stewart are involved, in house counsel seem determined not to let their counterparts know what they are thinking or doing. 
utory successors whose role in the inaking of the derivative work was negligible if not nonexistent.

Two preliminary inatters sliould be addressed before turning to a discussion of the pohicy interests at stake. First, Stewart applies ouly to underlying properties copyriglited before 1978 wlose creators died during the initial term; underlying works copyrighted on or after January 1, 1978, are not subject to the renewal provisions of the 1909 Act. ${ }^{145}$ The effects of the decision, however, will continue to be felt for a long time. Because the 1976 Act preserved the renewal system of the 1909 Act for all works in their imitial term as of January $1,1978,{ }^{146}$ the renewal terms of which can begin as late as 2005 , the inakers of a motion picture produced in the early years of the next century that makes use of a pre-1978 underlying work will still be required to obtain grants froin statutory successors or risk an action for infringement. Furthermore, a film reinoved from circulation out of fear of infringeinent might be withheld from the public until as late as 2052 , the last year in whicl an underlying work copyrighted under the 1909 Act will be protected. ${ }^{147}$

Second, although this discussion focuses on the effects of Stewart on copyrighted motion pictures, ${ }^{148}$ most of the analysis apphies equally to other derivative works placed at risk by the decision. Plays or television programs based on copyrighted novels, sound recordmgs of copyrighted musical coinpositions, textbooks incorporating copyrighted articles, and computer programs adapted from existing copyrighted software are just a few examples of other works that are subject to the same hazards as derivative motion pictures. ${ }^{149}$

\section{A. The Purposes of Copyright Legislation}

\section{Ensuring Broad Public Availability of Copyrighted Works}

The Constitution states that Congress 1nay grant copyrights to authors for the purpose of "proinot[ing] the Progress of Science and Use-

145. 1976 Act, 17 U.S.C. $\S \S 302-303$ (1988).

146. Id. §304(a).

147. Works in their first term as of January 1, 1978, are now entitled to an initial term of twenty-eight years and a renewal term of forty-seven years. Id. Thus, a work copyrighted in 1977 would enter its renewal term in 2005 and would not enter the public domain until 2052. Constitutional considerations, lowever, might prohibit granting the underlying proprietor a veto power during the additional nineteen-year renewal term added by the 1976 Act. See Roth v. Pritikin, 710 F.2d 934, 939 (2d Cir.), cert. denied, 464 U.S. 961 (1983) (stating that divestiture of copyriglit interests by retroactive legislation could be viewed as an unconstitutional taking).

148. Virtually all inotion pictures are derivative works insofar as they incorporate an underlying script. Ninnner, supra note 96 , at 30 ; see Jaszi, supra note 76 , at $718-20$. Only the class of films based on scripts written by studio einployees would be exempt froin the effects of Stewart. See infra note 180 .

149. Studios' Amicus Brief, supra note 4, at 21 n.32. 
ful Arts." 150 In accordance with this provision, the courts have taken a utilitarian approach to copyright. ${ }^{151}$ Financial reward to the author is viewed as a means to the ultimate end: the creation and dissemination of works for the public welfare. As the Supreme Court has explained:

The limited scope of the copyright holder's statutory monopoly, like the limited copyright duration required by the Constitution, reflects a balance of competing claims upon the public interest: creative work is to be encouraged and rewarded, but private motivation must ultimately serve the cause of promoting broad public availability of hterature, music, and the other arts. The immediate effect of our copyright law is to secure a fair return for an "author's" creative labor. But the ultimate aim is, by this incentive, to stimulate artistic creativity for the general public good. ... [T] he Copyright Act must be construed in hight of this basic purpose. ${ }^{152}$

Congress and the Copyright Office have expressed the same view. ${ }^{153}$

This approach seems virtually required once it is understood that copyright is a monopoly with the same risks and burdens that any monopoly entails. ${ }^{154}$ In his seminal work on copyright law, Professor

150. U.S. CONST. art. I, \& 8, cl. 8.

151. This approach differs from the "natural rights" view adopted by many European countries. See generally Russell J. DaSilva, Droit Moral and the Amoral Copyright: A Comparison of Artists' Rights in France and the United States, 28 BuLL. CopYright Soc'Y U.S.A. 1 (1980); Jane C. Ginsburg, A Tale of Two Copyrights: Literary Property in Revolutionary France and America, 64 TuL. L. REv. 991 (1990); Robert C. Hauhart, Natural Law Basis for the Copyright Doctrine of Droit Moral, 30 CATH. LAW. 53 (1985).

152. Twentieth Century Music Corp. v. Aiken, 422 U.S. 151, 156 (1975) (footnotes omitted); accord Sony Corp. of Am. v. Universal City Studios, 464 U.S. 417, 429 (1984) (explaining that the limited monopoly "is imtended to motivate the creative activity of authors and inventors by the provision of a special reward, and to allow the public access to the products of their genius after the limited period of exclusive control has expired"); Mazer v. Stein, 347 U.S. 201, 219 (1954) ("The economic philosophy behind the clause empowering Congress to grant patents and copyrights is the conviction that encouragement of individual effort by personal gain is the best way to advance public welfare through the talents of authors and inventors ...."); United States v. Paramount Pictures, 334 U.S. 131, 158 (1948) ("The copyright law, like the patent statutes, makes reward to the owner a secondary consideration... [R]eward to the author or artist serves to induce release to the public of the products of his creative gemius."); Washingtonian Publishing Co. v. Pearson, 306 U.S. 30, 36 (1939) (stating that copyright law aims to encourage the production of literary works of lasting benefit to the world); Fox Film Corp. v. Doyal, 286 U.S. 123, 127 (1932) ("The sole interest of the United States and the primary object in conferring the monopoly lie in the general benefits derived by the public from the labors of authors.").

153. See H.R. REP. No. 2222, 60th Cong., 2d Sess. 7 (1909) (report on the 1909 Act stating that copyrights are given "[n]ot primarily for the benefit of the author, but primarily for the benefit of the public"); REgISTER OF COPYRIGHTS, 87TH CONG., 1ST SESS., REPORT ON THE GENERAL REVISION OF THE U.S. COPYRIGHT LAW 5 (H.R. Judiciary Comm. Print 1961) [hereinafter REPORT OF THE REGISTER of COPYRIGHTS] ("As refiected in the Constitution, the ultimate purpose of copyright legislation is to foster the growth of learning and culture for the public welfare, and the grant of exclusive rights to authors for a hinited time is a means to that end.").

154. These dangers were eloquently discussed by Judge Hand (in a noncopyriglit context) in United States v. Aluminum Co. of Am., 148 F.2d 416 (2d Cir. 1945). While it is true that copyright may be somewhat less offensive than a typical trade monopoly because of its regulated scope and duration, Thomas Jefferson argued that "the benefit even of limited monopolies is too doubtful to be 
Chafee notes that copyright "burdens both competitors and the public"; therefore, "remembering that it is a monopoly, we must be sure that the burdens do not outweigh the benefits."15s In applying the copyright laws, the courts have traditionally been sensitive to this tension between the monopoly granted to authors and the public's interest in maintaining access to authors' works.

Most of the time the twin aims of copyright protection will function harmomiously with one another. The balance must be struck in favor of the public welfare when the two goals are in opposition, however, beeause the Constitution has been interpreted as making the broad dissemination of works to the public the ultimate objective of copyright protection and the guarantec of a fair return to authors secondary. As the Register of Copyrights once stated, "[t] $]$ here are many situations in which copyright restrictions would inhibit dissemination, with hittle or no benefit to the author. And the interests of authors must yield to the public welfare where they conflict."156

There is every reason to beheve that the Stewart decision will frustrate the fundainental policy of providing broad public access to copyrighted works. ${ }^{157}$ This danger will manifest itself both in the selective withdrawal of existing motion pictures from the inarketplace and in the deterrent from the production of certain new derivative films. The Stewart decision will likely turn the domain of derivative works and renewal terms into "a gaine of chess in which the public can be checkmated."158

\section{a. Existing Derivative Films}

Faced with the risk of lawsuits for exhibiting derivative motion pictures based on underlying works whose authors died during the initial terins of protection, motion picture studios have two options to avoid contimuing hability for copyright infringement. They may either negotiate with the owners of the renewal copyriglits to purcliase new hicenses entitling them to continued exploitation of the films or withdraw the

opposed to that of their general suppression." 5 WRITINGS OF THOMAS JEFFERSON 47 (Ford ed. 1895). In any event, this distinction is of limited significance while copyright protection is in force, and thus may be ignored for the purposes of this Comment.

155. Zechariah Chafee, Jr., Reflections on the Law of Copyright (pt. 1), 45 CoLuM. L. REv. 503, 506 (1945).

156. RePORT OF THE Register OF COPYRIGHTS, supra note 153, at 6.

157. As Professor Jaszi tellingly predicted in the pre-Stewart era:

[T]o adopt the rule of subordination as an overall solution to the problem of conflicts between underlying work owners and owners (and other users) of derivative works would be contrary to the constitutionally prescribed objectives of the American copyright system, ... because it fails to take into account the public interests which the copyright system is designed to promote and would operate in practice to disserve thosc interests.

Jaszi, supra note 76 , at 749 .

158. Morrissey v. Procter \& Gamble Co., 379 F.2d 675, 679 (1st Cir. 1967). 
films from the marketplace until the underlying material enters the public domain at the end of its renewal term.

The Ninth Circuit in Abend called the risk that studios would withdraw derivative films "remote," optimistically concluding that the owners of copyright in the motion picture and in the underlying work's renewal would "likely ... reach a mutually beneficial financial arrangement which will ensure contimued public access to the films."159 The Supreme Court expressed a similar belief in the ultimate success of bargaining: "Presumably, [Abend] is asking for a share in the proceeds because he wants to profit from the distribution of the work, not because he seeks suppression of it."160 Unfortunately, both courts oversimplified the problem.

To begin with, negotiations are not always successful. As Professor Cooter argues in his analysis of the Coase Theorem ${ }^{161}$ as apphed to bargaining game theory, the real obstacle to cooperation and production (that is, mutually beneficial redistribution) is not the transaction costs of bargaining but rather bargaining game strategy, which requires that parties sometimes disguise their intentions. ${ }^{162}$ Thus, even in a purely redistributive zero-sum game where there are no costs of communication, negotiation, or enforcement, noncooperative outcomes are possible: "There is no guarantee that the rational pursuit of self-interest will permit agreement." 163 Even when "the equilibrium is rational in the sense that every individual is maximizing his expected utility, and everyone's expectations are accurate, ... [n]oncooperative outcomes occur because each player's strategy is best against opponents on average, but not best agamst every individual opponent."164

Professor Cooter's analysis is particularly appropriate to the entertainment industry, which is somewhat umique in the business world. Hollywood consists of a core group of mutually dependent repeat "players," and today's litigation opponent is often toniorrow's partner. The game is dealmaking, and negotiating power determines the winner. ${ }^{165}$ It would therefore not be inconceivable for one who owns the copyrights of

159. Abend v. MCA, Inc., 863 F.2d 1465, 1477 n.15 (9th Cir. 1988), aff'd, 110 S. Ct. 1750 (1990).

160. Stewart v. Abend, 110 S. Ct. 1750, 1764 (1990).

161. The Coase Theorem is derived from R.H. Coase, The Problem of Social Cost, 3 J. LAw \& EcoN. 1 (1960). Calabresi expressed the Theorem as follows: "[M]f one assumes rationality, no transaction costs, and no legal impediments to bargaining, all misallocations of resources would be fully cured in the market by bargains." Guido Calabresi, Transaction Costs, Resource Allocation and Liability Rules-A Comment, 11 J. LAW \& EcoN. 67, 68 (1968).

162. Robert Cooter, The Cost of Coase, 11 J. Legal STud. 1, 23 (1982).

163. Id. at 17.

164. Id. at 28 .

165. See Mark Harris \& Gregg Kilday, Power 101, ENT. WKLY., Nov. 1, 1991, at 22 (comparing power in the entertainment industry to a game). 
several underlying works simply to stonewall one negotiation in order to raise bargaining power for the next. With nothing in the Copyright Act to prevent an author or copyright owner from keeping a protected work from the public altogether, ${ }^{166}$ a recalcitrant renewal owner might choose simply to retire the work and, consequently, all derivative works based thereon.

Negotiations might stall for other reasons. An author might be dissatisfied with the derivative film based on her work and choose to use renewal as a veto against continued distribution. Alternatively, the renewal owner might make such exorbitant demands that negotiation becomes futile, as it did when Sheldon Abend demanded 50\% of the gross proceeds in excess of advertising expenses from any rerelease of Rear Window. ${ }^{167}$ While continued negotiations might be beneficial to a studio in the case of a successful film such as Rear Window, one can imagine studio executives throwing up their hands when discussing a less financially important property and opting to withdraw the picture from circulation. ${ }^{168}$ The possibility of such an outcome highlights Professor Chafee's observation that "the veto power of the copyright owner loses most of its desirability on the author's death and inay become a nuisance when it passes to his descendants." 169

Successful negotiations between derivative- and underlying- work proprietors are further hindered when a large number of underlying properties are incorporated into a single derivative work. With popular inotion pictures mcreasingly resembling extended music videos, it is not unusual for one film's soundtrack to mclude a dozen copyrighted

166. See Fox Film Corp. v. Doyal, 286 U.S. 123, 127 (1932) ("The owner of the copyright, if he pleases, inay refrain from vending or licensing and content himself with simply exercising the right to exclude others from using his property.").

167. Petitioners' Brief, supra note 102, at 35 n.61. This would give Abend, who paid $\$ 650$ plus $10 \%$ of future proceeds for the renewal rights in Woolrich's story, \$6 million from the film's 1982 reissue alone (not accounting for promotional expenses). See Abend v. MCA, Inc., 863 F.2d 1465, 1468 (9th Cir. 1988), aff'd, 110 S. Ct. 1750 (1990).

168. Studio executive George Feltenstein speculated after the Ninth Circuit's decision: " 'The likely effect ... . will be to keep some inovies out of release. If we have to go back and renegotiate story rights for large amounts of money on anything but major films, we'll probably decide to forgo releasing the picture.' " Eder, supra note 138 (quoting George Feltenstein, programmer for MGM/ UA). Two years later, Mr. Feltenstein confirmed that his prediction had proved accurate. Telephone Interview with George Feltenstein, Vice-President of Sales and Marketing for MGM/UA (Mar. 28, 1991). Those who question whether the American public really needs continued aceess to box-office failures should note that the present-day classics The Wizard of $\mathrm{Oz}_{2}$, It's a Wonderful Life, and Citizen Kane (regarded by many critics as the greatest film ever made) were all commercial disasters in their initial releases. Juliann Garey, Turkeys Through Time, ENT. WkLY., Nov. 22, 1991, at 90, 91 (The Wizard of Oz); You Must Remember These, ENT. WkLY., Jan. 10, 1992, at 16, 25 (It's a Wonderful Life); JAMes Howard, The Complete Films of ORson Welles 49 (1991) (Citizen Kane).

169. Zechariah Chafee, Jr., Reflections on the Law of Copyright (pt. 2), 45 Colum. L. REv. 719, 725 (1945). 
songs. ${ }^{170}$ Moreover, a film miglit incorporate television clips, works of fine art, famous characters, or numerous other types of copyrighted material in addition to the underlying story. Even a film with a completely original plot might qualify as a derivative work with respect to these otlier varieties of underlying inaterial and so come within the reach of Stewart. ${ }^{171}$ When one combines the large number of underlying works potentially incorporated im a motion picture with the difficulty of tracing all of their copyrights through private bequests and intestate successions, the process of securing new licenses from renewal holders could be daunting indeed. The inere cost of researching the copyriglit histories of films might prevent studios froin investing their resources im anything but inajor films. Even if this financial hurdle were overcome, a studio miglit still quite rationally elect to withdraw a film froin distribution ratler than risk liability for copyright infringement if the statutory successor to one or inore of the underlying works cannot be located. ${ }^{172}$

As long as the underlying work is still protected, these problems do not subside when the copyriglited picture is not renewed and passes into the public doinain. In dismissing the new-property-right theory, the Stewart Court tacitly approved the "copyriglit ambush" effect of cases like Filmvideo and Russell. ${ }^{173}$ The import of the Court's holding is that only the discrete elements contributed by the derivative-work owner fall into the public doinain; any perfornance of the motion picture would infringe the incorporated elements of the protected underlying work, and unsuspecting members of the public who exhibit public-doinain films could find theinselves liable. In fact, the only person who could exhibit the inotion picture witlout infringing the source inaterial is the proprietor of the copyright in the underlying work. The public-domain policy of the Copyriglit Act is clearly frustrated by this result. ${ }^{174}$

Any remaining skepticism about Stewart's effect on the forced withdrawal of films froin the inarketplace should be alleviated by the recognition that such withdrawal frequently occurred before the Second Circuit decided Rohauer. When the film in question was not profitable enough to interest the studio in renegotiating for the renewal riglits, it was taken out of distribution. ${ }^{175}$ Often all prints and negatives were destroyed, for-

170. See Studios' Amicus Brief, supra note 4, at 20.

171. See id. at 3 n.4.

172. Id. at 20.

173. See supra notes $67-73$ and accompanying text.

174. The Court's definitive rejection of the new-property-right theory means that side effects of Stewart will continue to be felt long after 2052, the last year in which the direct effects of Stewart will be relevant. See infra text accompanying notes 366-68.

175. Films withdrawn due to potential infringement actions by owners of renewal copyrights in underlying works include Thanks for the Memory (starring Bob Hope), You Can't Take It With You (starring James Stewart and Lionel Barrymore), George Washington Slept Here (starring Jack Benny and Ann Sheridan), The Man Who Came to Dinner, Night Has a Thousand Eyes, The Black Angel, 
ever depriving the public of the chance to enjoy these movies. ${ }^{176}$ Withholding can be permanent even when such destruction does not take place because preservation of old films requires duplication, which would constitute infrimgement under Stewart if done without the copyright owner's permission. ${ }^{177}$ With studios facing greater risks of hability and diminished financial incentives to nnake older films available to the expanding cable and video markets, the American public might thus be deprived, teinporarily or permanently, of more than a thousand classic motion pictures. ${ }^{178}$

\section{b. New Derivative Films}

In addition to hindering the continued distribution of existing derivative films, the Stewart decision also provides a disincentive to the creation of new derivative works and thereby defeats the constitutional goal of stimulating artistic creativity. ${ }^{179}$ The creation of any derivative work based on an underlying work (other than a work made for hire ${ }^{180}$ ) created froin 1964 through $1977^{181}$ whose author is still living subjects the derivative-work owner to a risk of infringement upon the author's death. If renewal rights cannot be obtained froin statutory successors, motion picture owners might be forced to retire films early and cut short the terms of exploitation for which they have negotiated and on which they

Deadline at Dawn, and numerous others. See Mills Music, Inc. v. Snyder, 469 U.S. 153, 183 n.8 (1985) (White, J., dissenting); Jaszi, supra note 76, at 740; Nevins, supra note 106, at 602 n.10. Other films such as Gone With the Wind, My Fair Lady, and Dr. Zhivago survived because studios were able to renegotiate with successors. See Mills Music, 469 U.S. at 183 n.8 (White, J., dissenting); Cox, supra note 139. Films that could currently be affected include those based on works by authors such as Eugene O'Neill (Strange Interlude, Ahl Wilderness), Ernest Hemingway (To Have and Have Not), Raymond Chandler (Farewell My Lovely, The Lady in the Lake, The Big Sleep), Patrick Hamilton (Gaslight), Ian Fleming, and Jacqueline Susann. Eder, supra note 138.

176. Nevins, supra note 50 , at 63 ; $c f$. Jaszi, supra note 76 , at 741 (suggesting that Stewart-type claims "tend to discourage the efforts of film archives to preserve and restore deteriorating film materials").

177. Settle, supra note 116 , at 1094. It is likely, however, that such reproduction would constitute a noninfringing fair use under 17 U.S.C. $\$ 107$.

178. See Sugarman \& Salvo, supra note 5 (estimation that over a thousand films will be affected). The predicted conscquences are already being felt. At this writing, the classic 1953 Leslie Caron heart-tugger Lili is being pulled indefinitely from theatrical and home-video distribution by Turner Entertainment due to a pending lawsuit brought by the estate of underlying author Paul Gallico. Peter Stack, Something Else, S.F. CHRON., Mar. 28, 1991, at E2.

179. See supra notes $150-53$ and accompanying text.

180. A work made for hire is considered the work of authorship of the employer or other person for whom the work was prepared, and thus does not require renegotiation upon renewal. 1909 Act, 17 U.S.C. $\S 24$ (1976) (originally enacted as Act of Mar. 9, 1909, ch. 320, $\$ 23,35$ Stat. 1075, 1080); 1976 Act, 17 U.S.C. § 201(b) (1988).

181. As of 1992, such a work would still be in its first term of copyright and subject to the renewal provisions of the 1909 Act. With each passing year, the window of danger closes by one year. Thus, in 1993 underlying works copyrighted from 1965 through 1977 would be sources of risk. By 2006, all underlying works copyrighted under the 1909 Act will have entered their renewal term, and the Stewart risk facing new productions will disappear. Nimmer, supra note 96 , at 33 . 
might be relying to recoup their investments. ${ }^{182}$

Motion picture proprietors might conceivably reduce this danger by protecting themselves upon the film's creation through securing hicenses from likely successors. This is an unrealistic and impractical task, however, because it is impossible to determine who the author's statutory successors will be before the underlying work's renewal term commences. Purchasing the renewal expectancies of apparent successors, at a potentially prohibitive cost, buys the derivative-work owner no guarantees: if the author marries, divorces, or has additional children between the time of the assignments and the commencement of the renewal period, the successors to the renewal term under section 24 will change, ${ }^{183}$ leaving the studio holding worthless expectancies.

The risk of failing to obtain assignments of renewal expectancies from all ultimate successors is somewhat reduced because successors under section 24 take the renewal interest as tenants in common. ${ }^{184}$ Thus, a film owner could acquire from one successor nonexclusive rights with respect to the whole work; this would be sufficient to allow continued distribution, although it would provide no protection if sequels or remakes were desired. ${ }^{185}$ In his analysis of Stewart, David Nimmer (the current author of Nimmer on Copyright) rehes on this point to support his contention that predictions of the decision's effects have been exaggerated. ${ }^{186}$ However, overrehiance on this detail is misplaced. As Nimmer recognizes, a single co-owner might be barred from acting independently when the hicense would significantly harm the value of the

182. Rear Window itself provides a clear example of this danger. The movie was copyrighted in 1954; the 56-year period of protection under the 1909 Act would have entitled Stewart, Hitchcock, and the film's other owners to realize an economic return on their investment until 2010. (The extension provided by $\S 304$ (a) of the 1976 Act would have protected the film until 2029.) Instead, under the Stewart decision, their rights were cut off in 1970 at the end of the first term of protection for Woolrich's story, leaving them with a copyright term of only 16 years. "[I]f Alfred Hitchcock had known that his right to distribute and exhibit Rear Window might termmate after only sixteen years were Woolrich to die before the renewal term in the short story, he might never have made the inotion picture...." Studios' Amicus Brief, supra note 4, at 22-23. With the average production cost for a motion picture reaching as high as $\$ 26$ million, Anne Thompson, Action Figures, ENT. WkLY., Apr. 5, 1991, at 6, a studio may reasonably be reluctant to risk producing a film whose exhibition period may be unpredictably cut short.

183. Bricker, supra note 23, at 33, cited with approval in Rohauer v. Killiam Shows, Inc., 551 F.2d 484, 493 (2d Cir.), cert. denied, 431 U.S. 949 (1977).

184. 1976 House REPORT, supra note 16, at 141-42; cf. Pye v. Mitchell, 574 F.2d 476, 480 (9th Cir. 1978) (stating that joint authors automatically become holders of an "undivided interest in the whole" work); Picture Music, Inc. v. Bourne, Inc., 314 F. Supp. 640, 646 (S.D.N.Y. 1970) (stating that co-owners of a joint work hold their interests as tenants in common), aff'd, $457 \mathrm{~F} .2 \mathrm{~d} 1213$ (2d Cir.), cert. denied, 409 U.S. 997 (1972).

185. Of course, even the Rohauer solution would require new licenses from the statutory successors for sequels or remakes.

186. Nimner, supra note 96 , at $33,34-36 \&$ n.75. 
copyright for the other owners. ${ }^{187}$ While Nimmer expresses hope that this argument would not extend to the Stewart scenario, ${ }^{188}$ it is certainly possible that courts will refuse to recognize the validity of a license executed by one of several renewal owners. ${ }^{189}$

\section{Rewarding Authors for Their Creative Efforts}

Courts and commentators have consistently interpreted copyright legislation as subordinating financial reward to authors to the ultimate objective of pronoting broad public access to creative works. ${ }^{190}$ Compensating authors is nonetheless a justifiable aim of the statute, as authors will be more likely to produce works for the public if they are guaranteed the opportunity to collect adequate earnings for thernselves and their families. Although Stewart effectively resolved its balancing of interests in favor of the authors of underlying works, the irony is that it is precisely those authors who might be inost adversely affected by the decision. Two significant risks are involved.

The first and nore obvious of these dangers is that authors of underlying properties subject to Stewart (that is, underlying properties currently in their mitial term) will now have diminished opportunities to realize an economic benefit from the sale of inotion picture rights because studios will be reluctant to acquire such rights. ${ }^{191}$ As the risk increases that the author might die before the commenceinent of the renewal term (because the author is elderly or in poor health) or that the potential period for exploitation of the film might be particularly brief (because the underlying work is nearing the end of its mitial copyright term), prospective purchasers of inotion picture rights will be less likely to negotiate. Thus, far froin giving authors the second bite at the apple that the Supreine Court found so important, Stewart might deprive authors of a first chance to profit froin the sale of derivative rights to their works. ${ }^{192}$ Even David Nimmer, a supporter of the Stewart decision, acknowledges that "soine studios inay simply choose the easy path for future projects and categorically reject $A b e n d$-risk works rather than seeking a safe path through the jungle." 193

187. Id. at 35 n.75. A co-owner would also be barred from so acting when all owners have agreed in advance to act only unanimously. Id.

188. Id.

189. Cf. Shapiro, Bernstein \& Co. v. Jerry Vogel Music Co., 73 F. Supp. 165, 168 (S.D.N.Y. 1947) (recognizing that use of copyright by one co-owner unay destroy value of copyright for others).

190. See supra notes $150-56$ and accompanying text.

191. See Stewart v. Abend, 110 S. Ct. 1750, 1777 (1990) (Stevens, J., dissenting) ("Ironically, by restricting the author's ability to consent to creation of a derivative work with independent existence, the Court may make it practically impossible for the original author to sell his derivative rights late in the original term ....."); Studios' Amicus Brief, supra note 4, at 10 n.15.

192. See Scher, supra note 116 , at 175 .

193. Nimmer, supra note 96 , at 36 . The danger is not limited to underlying literary works. One 
There is a second, hidden peril to authors that calls into question the effectiveness of the Court's paternalistic attitude. The situation in which it arises is this: an elderly author who has assiduously avoided any ancillary exploitation of a work created in earlier years wishes to cash in on his asset before his death. ${ }^{194}$ If the work is still in its first term (and particularly in the later years of that term), he is likely to have difficulty transferring his work unless the purchaser can obtain hicenses from all identifiable ineinbers of the heir class. ${ }^{195}$ If the author and his children are estranged, ${ }^{196}$ the heirs might elect to stonewall in their negotiations with the purchaser. In this way, the author is put in the unenviable position of having to plead with his children to go along with the deal, and the children are in a position to deinand large sums from the author in exchange for their required licenses. As unsettling as it inay be to consider the possibility of heirs resorting to such extortion, a studio source not ouly confirms that this scenario has already coine to pass but believes that it might prove the most significant problem with the Stewart decision.

Given these potentially severe consequences, it is far froin clear that authors desire the protection froin theinselves that the Stewart Court felt compelled to accord thein. As the Court itself discerningly observed in Fred Fisher:

It is not for courts to judge whether the interests of authors clearly lie upon one side of this question rather than the other. If an author cannot make an effective assignment of his renewal, it may be worthless to him when he is most in need. ... [W] cannot say that such men would regard with favor a rule of law preventing thein from realizing on their assets when they are most in need of funds. Nor can we be unmindful of the fact that authors have themselves devised means of safeguarding their interests. We do not have such assured knowledge about authorship ... as to justify us as judges in importing into Congressional legislation a denial to authors of the freedom to dispose of their property possessed by

source at a major studio revealed that the studio has adopted a policy of avoiding all music with a

"Rear Window problem" (that is, copyrighted between 1964 and 1977). It is probable that other studios have embraced similar strategies. Cf. 1 N1MMER \& NIMMER, supra note 15, § 3.07[A], at 346 (explaining that a film producer might decline to synchromize a pre-1978 song in its initial copyright term for fear of later Stewart problems).

194. It is not unusual for authors who could net a significant financial reward for derivative rights to their properties to nonetheless refuse to authorize derivative works. For example, J.D. Salinger has persistently rejected lucrative offers for the motion picture rights to The Catcher in the Rye. John M. Wilson, Outtakes: Matt Salinger Plays the Waiting Game, L.A. TIMES, Oct. 28, 1990, Calendar, at 34.

195. Although a license from only one of the author's statutory successors would be sufficient to permit continued distribution of the motion picture, see supra text accompanying notes 184-89, licenses from all potential successors would still be required because there is no way to identify the actual successors until the renewal vests. If the purchaser obtains a license from one of the author's children and that child predeceases the author, the liccnse will be meaningless.

196. See, eg., Saroyan v. William Saroyan Fonnd., 675 F. Supp. 843 (S.D.N.Y. 1987). 
others. While authors may have habits making for intermittent want, they may have no less a spirit of independence which would resent treatment of them as wards under guardianship of the law. ${ }^{197}$

\section{B. The Equities and Derivative Works}

\section{The Nature of Derivative Works}

Professor Nevins has provided two conflicting conceptual models of derivative works. ${ }^{198}$ The "appendage model" determines a derivative work's aesthetic worth and legal status by its relationship to the source naterial. ${ }^{199}$ This nodel represents the traditional view derived from an historic commitment to hiterature over other creative media. ${ }^{200}$ Anyone who has ever condemned a movie for not remaining faithful to a favorite book or a Muzak version of a popular song for sacrificing the original's vitality and soul has viewed those works froin the standpoimt of the appendage model. Under a strict apphication of this model, the derivative work is valueless as a separate entity; the withdrawal of a film from circulation for a term of years because of a failure to obtain renewal rights in the source inaterial would, therefore, not represent a significant public loss. ${ }^{201}$

In contrast, the "free agent" model represents the more modern view and is accepted by those who regard all creative media as aesthetically equal. ${ }^{202} \mathrm{~A}$ proponent of this model regards the derivative work, once created with the consent of the source-work author, as a separate entity and judges its aesthetic value and legal status aceording to its own inherent qualities. ${ }^{203}$ As Professor Nevins points out, it would be unthinkable to judge Michelangelo's Sistine Chapel ceiling by its fidehty to biblical accounts of the Last Judginent. ${ }^{204}$ Those who perceive the derivative work's aesthetic value as having little or nothing to do with the extent to which the source work's "essence" is captured therein consider it irrational to accord the source work's author the legal power to terminate the life of the derivative work. ${ }^{205}$ "For those who adopt this view, copyright principles should not be interpreted so as to permit such aesthetically disastrous results." 206

Professor Nevins implies that the appendage model underlies the

197. Fred Fisher Music Co. v. M. Witmark \& Sons, 318 U.S. 643, 657 (1943).

198. See Nevins, supra note 50 , at $60-62$.

199. Id. at 60.

200. Id.

201. Id. at $60-61$.

202. Id. at 61 .

203. Id. at 60 .

204. Id. at 62 .

205. Id. at 61 .

206. Id. 
line of cases espousing the subordination theory. ${ }^{207}$ This seems plainly wrong, however-at least at anything other than a subconscious level. Certainly the Supreine Court in Stewart inade no evaluation of the fidelity of Rear Window to It Had to Be Murder. The subordination theory rehies not on aesthetic judgments but rather on conceptions of property rights and the protective purposes of the renewal term. Nevertheless, the models provide a starting point in understanding the inequity of permittimg a proprietor of an underlying work to exercise control over a derivative work.

The free-agent model not only is inore concordant with the policy of promoting broad public access to creative works, ${ }^{208}$ it also better reflects the realities of inotion picture production. ${ }^{209}$ As Professor Nevins says about the late Jolin Huston, who directed a large number of movies based on novels and plays:

In every case ... Hustou altered the source work-sometimes minimally as with [Dashiell] Hammett's novel The Maltese Falcon, more often radically as with [Maxwell] Anderson's blank verse play Key Largo-until the film was transformed into a personal work of the director himself, interconnected thematically with his other films and with his offscreen life and concerns, reflecting the personality not of the source work author (or if so only incidentally) but of Huston the film-maker. Huston's procedure in transforming source works is not at all unusual in Hollywood and is the normal mode in which directorial creativity operates. ${ }^{210}$

Alfred Hitchcock himself was only minimally faithful to the source material. In his deposition at the start of the Rear Window hitigation, Hitchcock explained:

I looked at [Woolrich's story] like I would any other story I'm going to make into a picture. That is to say, I read it once, and I throw it away, because I make a picture. I do not make a book into a picture. ...

.... films. ${ }^{211}$

That's why they're called Hitchcock films and not Woolrich Hitchcock estimated that the final screenplay of Rear Window was "20

207. See id. at 60 ("Whatever rule a court adopts on these issues presupposes some model in the judicial mind, some concept of a derivative work's nature . ...").

208. Professor Nevins notes that the free agent model

serves the vital policy function of helping to preserve the cultural heritage of the American people by promoting both the derivative work owner's right to make the work available throughout its copyright term and the right of any person to continue making the derivative work available after it has passed into the public domain.

Id. at 62 (footnote omitted).

209. It is conceded that the appendage model may be more apropos with regard to other classes of derivative works, such as abridgments and reproductions.

210. Nevins, supra note 50 , at 61 n.9.

211. Joint Appendix at 17, Stewart v. Abend, 110 S. Ct. 1750 (1990) (No. 88-2102). 
percent Cornell Woolrich and 80 percent Hitchcock."212 Of course, this approximation relates only to additions to the script, a small part of the film as a whole. The additional imgredients of Hitchcock's direction and Stewart's and Kelly's performances, which were probably more vital to the film's success than the story line, were zero percent Woolrich.

In considerimg derivative works, the Rohauer court pointed out that "a person who with the consent of the author has created an opera or a motion picture film will often have made contributions hiterary, inusical and economic, as great as or greater than the original author."213 The Supreme Court in Stewart recognized the validity of this characterization in some contexts but dismissed it as a justification for the new-propertyright approach by reasoning that some derivative works (for example, abridginents) might involve only minimal contributions to the underlying work. ${ }^{214}$ While this may be accurate, it does not change the fact that the Second Circuit's observation is particularly true im the case of inotion pictures, the class of works directly imphicated by the Stewart decision. ${ }^{215}$ Furthermore, it is noteworthy that Congress failed to distinguish among different types of derivative works in the termination provisions of the 1976 Act, which "allow[ ] utilization after termination of all previously created derivative works, not just those which by their nature and in all fairness deserve special treatinent.".216

\section{Stewart's Creation of Inequities}

It follows froin the above depiction of a derivative motion picture that the author of an underlying work who renegotiates for the rights in the work's renewal term will receive the benefit of some significant value contributed solely by the filmmakers. Furthermore, the film's success-

212. Id. at 18. Among the elements added by Hitchcock and screenwriter John Michael Hayes were the fashion-model romantic interest portrayed by Grace Kelly, the comic masseuse played by Thelma Ritter, all the neighbors around the courtyard, the profession of James Stewart's character (photographer), and the telltale clue that leads to the murderer's undoing. Id. at 18-21.

213. Rohauer v. Killiam Shows, Inc., 551 F.2d 484, 493 (2d Cir.), cert. denied, 431 U.S. 949 (1977).

214. Stewart v. Abend, 110 S. Ct. 1750, 1763 (1990); accord Abend v. MCA, Inc., 863 F.2d 1465, 1477 (9th Cir. 1988), aff'd, 110 S. Ct. 1750 (1990).

215. See Mimms, supra note 36, at 620 . As Professor Jaszi explains:

As a class of derivative works, motion pictures have especially strong claims to independence. Although they often borrow from multiple elements of preexisting works on which they are based (mcluding characterization, plot, and non-narrative material), this borrowing, if the preexisting work in question is a novel, play, or even another motion picture, will always be seleetive-often highly so. . . . Invariably, the final motion picture represents a significant transformation of the preexisting material, both because it is a work in a different medium and because it mcorporates additions of new material.

Jaszi, supra note 76, at 737-38 (footnotes omitted).

216. Mimms, supra note 36, at 635. Although Professor Mimms is critical of this encroachment on the rights of authors, he concedes that "it would be difficult, if not impossible, to provide a set of criteria by which a derivative work could be judged to determine if its nature warrants continued exploitation." Id. at 636. 
and hence the willingness of its owners to pay more for renewal rightsis usually the result not ouly of the director's and actors' creative contributions but also of the producer's significant outlays for production and marketing costs. ${ }^{217}$ The disconcerting consequence is that the more creative and economic contributions the filmmakers invest in the motion picture's success, the greater bargaining power they give to the underlying author or his successors when negotiating the right to continue exploiting the film during the underlying work's renewal term. The filminakers might thus be compelled to pay more for renewal rights due to their own efforts and imvestment rather than due to any increased intrimsic value of the underlying work. This unearned dividend accorded to the proprietor of the underlying work seeins especially undeserved when it accrues to a copyright speculator such as Abend, ${ }^{218}$ who was uninvolved even in the creation of the underlying work.

Furthermore, the success of a derivative motion picture might increase the independent value of the underlying work beyond what the work would otherwise have earned. For example, after acquiring the renewal of Woolrich's story in 1971 for $\$ 650$ plus $10 \%$ of profits, Sheldon Abend capitalized on the suceess of the derivative movie, receivmg $\$ 30,000$ from Home Box Office for rights to a made-for-cable Rear Window reinake, $\$ 7,500$ plus royalties from book publishing, and several thousand dollars from miscellaneous hicenses. ${ }^{219}$ Abend even timied new print publications of the story in order to take advantage of the publicity surrounding the film's rerelease. ${ }^{220}$ Thus, far from being left with a valueless underlying work if demed a share in the derivative work, the source work's owner is free to capitalize not only on the underlying work's intrimsic value but also on the increased value resulting froin the derivative work's suceess.

Finally, there is a fundamental inequity in granting the underlyingwork author the right to profit from a film's commercial success when that author bears none of the risk of commercial failure. Every purchaser of motion picture rights einbarks on a speculative venture: the film might be a box-office flop or might not be produced at all. While a rights acquisition might be less of a gamble where a bestselling novel is

217. See Goldstein, supra note 13 , at 247 (contending that in negotiations for renewal rights the author inay benefit from value contributed solely by the producer).

218. Although Abend is frequently described as a "literary agent," Abend, 863 F.2d at 1467; Michael I. Rudell, $A$ View of Copyright Through 'Rear Window, 'N.Y. L.J., Jan. 27, 1989, at 3, or a "literary researclier," Cox, supra note 139, at 24, David Nimmer clarifies that Abend is in fact "a speculator who purchases contingent interests, and then seeks vindication of his rights through U.S. and foreign courts." Nimmer, supra note 96, at 25 n.25; cf. Nevins, supra note 50, at 62 (acknowledging the existence of such speculators).

219. Petitioner's Brief, supra note 102, at 33 n.57.

220. Id. 
involved or where a inajor star or director is committed to the project, ${ }^{221}$ this will presumably be reflected in the negotiation of a higher purchase price. In any event, it is reasonable to assume that the amount a studio is willing to invest in acquiring motion picture rights represents the market value of those rights, determined with full consideration of the likelihood of success. If, for whatever reason, the inovie is never inade or released, the author retains any sums advanced; the standard hterary purchase agreement even contains a reversion clause under which the author will recover all granted rights if the motion picture is not produced within a specified term of years. However sound the policy rationale might be for allowing an author to profit through the renewal term froin an unexpected increase im the market value of his own work, that rationale provides an imsufficient basis for permitting the author to receive a benefit from the unanticipated commercial success of the work of another.

As described earlier, the source-work owner has the power not only to reap a wimdfall froin the success of a derivative work but also to bar distribution entirely, either by refusing to negotiate or by demanding a higher price than the studio is willing to pay. ${ }^{222}$ The public may thus be temporarily or permanently deprived of the extensive creative contributions of the filmmakers by a person who had no role in the movie's production and possibly no role $\mathrm{m}$ the creation of the underlying work. It is difficult to imagine a more inequitable outcoine or one less consonant with the policies of copyright protection.

In his Abend dissent, Judge Thompson lamented the inequities of the Ninth Circuit's decision:

I don't see why Abend should be permitted to squeeze the defendants for money generated by a movie which they created, in which they risked their capital, and to which they committed their substantial talents. Granted, the defendants used Woolrich's story. But they paid him for it, and he agreed to assign his renewal rights in the story to thein. Now, because of the quirk of fate that Woolrich died before the renewal term of the copyright in the underlying story, Abend, according to the majority, is entitled to a portion of "Rear Window's" profits. It just doesn't inake sense. ${ }^{223}$

It is unlikely that authors will benefit under the regime of copyright law created by the Supreme Court in Stewart v. Abend. Creators of

221. Even these situations provide no guarantees. Legendary box-office flops include Heaven's Gate (directed by Oscar-winner Michael Cimino), Ishtar (starring Dustin Hoffman and Warren Beatty), and, most recently, Bonfire of the Vanities (based on the Tom Wolfe bestseller, directed by Brian de Palma, and starring Tom Hanks, Melanie Griffith, and Bruce Willis).

222. See supra notes 161-69 and accompanying text.

223. Abend v. MCA, Inc., 863 F.2d 1465, 1487 (9th Cir. 1988) (Thompson, J., dissenting), aff'd, 110 S. C.. 1750 (1990). 
derivative works certainly do not profit from it, and the American public, for whose benefit the Constitution authorized Congress to grant copyrights in the first place, is left in the worst situation of all. The final Part of this Comment will address the possibility of resolving this disorder through legislative action.

\title{
III
}

\section{Sweeping Up: A Proposal for Congressional Action}

\author{
"When am I going to see you again?" \\ "Not for a long time. At least, not until tomorrow night." \\ James Stewart and Grace Kelly exchanging a \\ temporary farewell in Rear Window ${ }^{224}$
}

In her opinion for the Court in Stewart v. Abend, Justice O'Connor rehed on the "second chance" policies of the renewal term and on the absence of clear evidence that Congress intended to limit these pohicies by barring an author from renegotiating grants of derivative rights that later proved to be more valuable than initially presumed. "Absent an explicit statement of congressional intent that the rights in the renewal term of an owner of a pre-existing work are extinguished upon incorporation of his work into another work, it is not our role to alter the delicate balance Congress has labored to achieve."225 Justice O'Connor conceded that the holding might not be "good policy," but claimed that it was mandated by the language of the 1909 Act and the cases decided under that Act. ${ }^{226}$ In response to the concerns urged by major motion picture studios in their amicus curiae brief, she expressed the Court's belief that "[t]hese arguments are better addressed by Congress than the courts."227

This language extends a clear mvitation to Congress to address the undesirable policy consequences of Stewart by legislative action. The Court had left the same door open in Miller Music, the precedent on which the Stewart decision turned. 228 Any attempt by Congress to alter the balance of rights declared by the Court through remedial legislation, however, is likely to meet vehement constitutional arguments from some

224. REAR WINDOW (Paramount 1954).

225. Stewart v. Abend, 110 S. Ct. 1750, 1765 (1990)

226. Id. at 1768 .

227. Id. at 1764 .

228. Miller Music Corp. v. Charles N. Daniels, Inc., 362 U.S. 373, 378 (1960) ("[T]here is symmetry and logic in the design of $\S 24$. Whether it works at times an injustice is a matter for the Congress, not for us."); see also Chamberlain v. Feldman, 89 N.E.2d 863, 865 (N.Y. 1949) ("[I]t may be contrary to sound policy to keep meritorious literary achievement out of the public domain for so long a time as is here involved.... [But] any such change of public policy must be the doing of the Legislature."). 
holders of renewal rights in underlying works. ${ }^{229}$ The claim will be that the Court's decision has conclusively defined their property rights under the 1909 Act and that such rights cannot be retroactively abrogated without violating Fifth Amendment protections. ${ }^{230}$ It is therefore necessary to examine the alternatives available to Congress and their potential for success in light of principles concerning retroactive legislation.

This Part begins by relying on the derivative-works exceptions of the 1976 Act to argue that Congress is sensitive to the special nature of these works, and thus disposed to considering a legislative solution to the Stewart problein. The Part then proposes an amendment to the 1976 Act desigued to reinedy the effects of the Stewart decision. The extent to which the amendment would solve the problems discussed in the previous Part would depend on the scope of its application. Thus, four alternatives for nominally prospective and retroactive application are discussed, with einphasis upon the effects of each application and their susceptibility to the inevitable constitutional challenges. Finally, this Part briefly discusses additional alternatives that Congress might use to soften the impact of Stewart.

\section{A. The Termination Exceptions of the 1976 Act: Congress' Recognition of the Special Case of Derivative Works}

The derivative-works exceptions in the 1976 Act, dismissed by the Court in Stewart as the result of a legislative compromise with special interest groups, ${ }^{231}$ are evidence of Congress' recoginition of the special concerns surrounding these works. ${ }^{232}$ While the exceptions apply to the riglit of termination after thirty-five years for works copyrighted under the $1976 \mathrm{Act}^{233}$ and to the right of termination at the beginning of the additional nineteen-year renewal period for subsisting copyrights, ${ }^{234}$ however, Congress did not make an exception for terminations resulting from the reversion at the end of the initial twenty-eight-year terin.

In Abend the Ninth Circuit concluded that Congress' failure to apply the termination exception for derivative works to the carryover of the 1909 Act's reversion provisions manifested its intent to leave deriva-

229. If speculations about the poteutially negative consequences of the Stewart decision for underlying-work proprietors prove accurate, resistance to a legislative change may be overestimated. Nevertheless, some challenges are virtually certain to occur.

230. See Roth v. Pritikin, 710 F.2d 934, 939 (2d Cir.), cert. denied, 464 U.S. 961 (1983) ("An interest in a copyright is a property right protected by the due process and jnst compensation clauses of the Constitution.").

231. Stewart, $110 \mathrm{~S}$. Ct. at 1762-63.

232. See 1976 HOuSE REPORT, supra note 16, at 124 ("Section 203 reflects a practical compromise that will further the objectives of the copyright law while recognizing the problems and legitimate needs of all interests involved.").

233. 1976 Act, 17 U.S.C. $\$ 203(b)(1)$ (1988).

234. Id. $\S 304(\mathrm{c})(\mathrm{G})(\mathrm{A})$. 
tive works subordinate to underlying works. ${ }^{235}$ The 1976 Act's legislative history behes this argument. Froin the beginning of the revision effort, the Register of Copyrights expressed dismay at the ambiguity of the renewal provisions of the 1909 Act. ${ }^{236}$ The Register's recommendation to continue this ambiguity was based not on tacit or express acceptance of the wording of the provisions but rather on concerns with upsetting existing contractual arrangements. ${ }^{237}$ The House Report on the revision adopted the Register's advice: "A great many of the present expectancies in these cases are the subject of existing contracts, and it would be unfair and immensely confusing to cut off or alter these interests." 238

The Supreme Court was correct in attributing the derivative-works exceptions in the 1976 Act to a process of compromise. The Motion Picture Association of America vigorously opposed the termination provisions, ${ }^{239}$ and the derivative-works exceptions may well have been a concession to the concerns of the motion picture industry. ${ }^{240}$ The exceptions do reveal, however, that Congress was responsive to thc probleins created by the termination of rights to underlying works. ${ }^{241}$ If the derivativeworks exceptions were in fact a concession, there is nothing to suggest

235. Abend v. MCA, Inc., 863 F.2d 1465, 1478 (9th Cir. 1988), aff'd, 110 S. Ct. 1750 (1990).

236. See REPORT OF THE REGISTER OF COPYRIGHTS, supra note 153, at 53 (lamenting that the renewal system "has largely failed to accomplish its primary purpose" and "has also been the source of more confusion and litigation than any other provision in the copyright law").

237. See id. at 57 ("It is unfortunate that the highly troublesome provisions for the reversion of renewal rights sliould continue in effect for 28 years longer, but we believe this is preferable to the confusion and unfairness that would result if existing renewal expectancies were cut off."); SUPPLEMENTARY REPORT OF THE REGISTER OF COPYRIGHTS, supra note 57, at 94 ("[T] his means perpetuating the complexities, uncertainties, and ambiguities of the renewal section for another 28 years ....").

238. 1976 HouSE REPORT, supra note 16 , at 139.

239. There inust always be a certain glamour in the idea of riding forth, like a knight of old, to rescue the maiden, authorship, from the dragon of unremunerative transfers. But the age when a mean-spirited publislier would offer no more than 5 pounds to John Milton for "Paradise Lost" is as dead and gone as the age of chivalry. Today, the dragon is a myth; the maiden, a muscular Brimnehilde; and the gallant knight, we fear, more nearly akin to Don Quixote than to St. George. ... [T] he notion that authors in the modern world need special legal protections against unremunerative transfers is simply unrealistic.

Register of COPYRIGHTS, 88TH CONG., 1st SESS., DisCusSion AND COMMENTS ON REPORT OF THE REgISTER OF COPYRIGHTS ON THE GENERAL REVISION OF THE U.S. COPYRIGHT LAW 362 (H.R. Judiciary Comm. Print 1963) (comments of the Motion Picture Association of America, Inc.).

240. "The right of termination was fought tooth and nail by the motion picture industry. To obtain industry support for at least some forn of termination right, some concessions had to be made ... " Peter F. Nolan, A Brighter Day for the Magic Lantern: Thoughts on the Impact of the New Copyright Act on Motion Pictures, 11 LOY. L.A. L. REV. 1, 32 (1977) (footnote oinitted).

241. Ellingson suggests that the broad scope of the exceptions, covering all derivative works rather than merely important or margiually derivative ones, attests to the extent of Congress' sensitivity to the deadlock problem rccoguized by the courts. Ellingson, supra note 58, at 29; see also Frank R. Curtis, Caveat Emptor in Copyright: A Practical Guide to the Termination-of-Transfers Provisions of the New Copyright Code, 25 BuLl. CoPYRIGHT Soc'Y U.S.A. 19, 55 (1977) (explaining that the 1976 Act 'recognizes that a 'derivative work' frequently involves significant authorship by 
that the concerns that forced this compromise were beheved to be any less apphicable in the renewal situation.

As the following discussion will argue, Congress was not constitutionally prevented from altering the relative rights of derivative and underlymg owners granted under the 1909 Act. $^{242}$ Furthermore, there is no indication that Congress feared due process violations were it to include a derivative-works exception in section 304(a). The House Report did express concern that it might be "unfair" to alter the expectancies under existing contracts by abandoning the renewal terin for subsisting works, ${ }^{243}$ but "unfair" is not the same as "unconstitutional."244 Additional support is found in the comments of the House Committee on the Judiciary regarding section 303, which replaced common-law perpetual protection for subsisting copyrights with statutory copyright for a limited term: "The committee beheves that a provision taking away subsisting common law rights and substituting statutory rights for a reasonable period is fully in harmony with the constitutional requirements of due process ...."245 The Committee's dismissal of due process concerns here and the absence of any expression of similar considerations in justifying the carryover of the renewal provisions in section 304(a) suggest that the decision to perpetuate the renewal system for subsisting works did not depend on constitutional considerations.

To be sure, there is no explicit statement of congressional imtent to exempt derivative works from the renewal provision of section 304(a). The argument that the exception was inadvertently omitted is weak, as Congress clearly knew how to provide for such an exception where it so desired. Rohauer was not decided until 1977, so one carmot claim that Congress took for granted the mdependence of derivative works in the Stewart situation. Nevertheless, the existence of the two derivativeworks exceptions in the 1976 Act indicates Congress' acknowledgment that the "second chance" rationale of the termination provisions must yield to the interest in continued utilization of derivative works. Given that the same protective rationale underlies the renewal system, ${ }^{246}$ it is reasonable to presume that Congress would be amenable to a similar accommodation of interests.

the derivative user and that it may be unfair to prohibit all further use of such work after termination or to subject its creator to the possibly exorbitant demands of the owner of an underlying work").

242. Contra Settle, supra note 116, at 1093 (suggesting that congressional alteration of the relative rights of derivative and underlying owners would constitute a taking of property in violation of the Due Process Clause).

243. See 1976 HouSE REPORT, supra note 16, at 139.

244. Fairness, however, may be a highly relevant consideration in determining whether a regulation violates the Takings Clanse of the Fifth Amendment. See infra notes 289 \& 336 and accompanying text.

245. 1976 House Report, supra note 16 , at 139.

246. See id. at 124 . 


\section{B. Repairing the Window: A Legislative Proposal}

Congress should amend section 304(a) of the 1976 Act, which carries over the renewal provisions of the 1909 Act for works in their first copyright term on January 1,1978, to include the following before the final clause:

And provided further, That such renewal and extension of the copyright in a preexisting work shall not affect the continued utilization of a derivative work prepared pursuant to a valid license during the original terin of copyright of the preexisting work, but this limitation does not extend to the preparation after the renewal and extension of other derivative works based upon the copyrighted work. ${ }^{247}$

The proposed language closely tracks that of the derivative-works exceptions of the 1976 Act. The amendment would eliminate the need for derivative-work proprietors to renegotiate for rights when the underlying work enters its renewal term. It would also solve the "copyright ambush" problein by permitting free use of derivative works in the public domam irrespective of the copyright status of the underlying material. Note that the amendment would permit only the continued utilization of the derivative work prepared under the original grant; the creation of additional derivative works such as remakes and sequels would require a new grant of rights. Furthermore, underlying-work owners would remaim free to limit contractually the original grant of rights as to duration and/or scope. ${ }^{248}$

The question as to what the reach of the amendment would be, however, remains. Congress would have at least four alternatives:

(1) apply the amendment to all underlying works with renewal terms beginning on or after the effective date;

(2) apply the amendment to all causes of action arising on or after the effective date, whether the underlymg work was in its initial or renewal term on the effective date;

(3) apply the amendment retroactively to all underlying works renewed under the 1976 Act, legitimizing preenactinent conduct that would otherwise have been infringing; or

(4) apply the amendment retroactively beyond the effective date of the 1976 Act to all existing underlying works.

On their face alternatives (1) and (2) are prospective while (3) and (4) are retrospective. However, the nominally prospective nature of the first two alternatives is deceiving; affixing an effective date on or after the amendment's enactinent does not immunize the legislation froin constitutional challenge. All four possibilities would diminish the value of underlying copyrights currently in their initial term by abrogating their

247. This language is suggested in part by Mimms, supra note 36, at 620 .

248. See supra note 94. 
proprietors' ability to renegotiate for continued use of the works during their renewal terms.

\section{Constitutional Vulnerability of the Proposed Amendment: The Problem of Retroactivity}

A brief discussion of retroactivity will reveal why even a prospective application of the amendment might be vulnerable to a constitutional challenge. One widely accepted definition of a retroactive statute is "one which gives to preenactment conduct a different legal effect from that which it would have had without the passage of the statute."249 The clearest example is a statute with an effective date that precedes its enactment. ${ }^{250}$ However, as Professor Kaplow has pointed out, this definition excludes nominally prospective statutes that alter the future value of past investments. ${ }^{251}$ Justice Story expanded the concept of retroactivity to mclude this latter group of statutes: "Upon principle, every statute, which takes away or impairs vested rights acquired under existing laws, or creates a new obligation, imposes a new duty, or attaches a new disability in respect to transactions or considerations already past, must be deemed retrospective ...."252 According to this definition, any law that destroys a right vested before the law's enactment is retroactive even if it applies only to cases arising prospectively. ${ }^{253}$ The effect of the Eigliteentli Amendment on those with investments in hquor businesses is an example of such "vested-riglits retroactivity."254 Decisions and commentaries on retroactive legislation have often advocated the vested rights definition in determining whether a statute is retroactive. ${ }^{255}$

249. Charles B. Hochman, The Supreme Court and the Constitutionality of Retroactive Legislation, 73 HARV. L. REv. 692, 692 (1960); see also Ray H. Greenblatt, Judicial Limitations on Retroactive Civil Legislation, 51 Nw. U. L. REv. 540, 544 (1956) (defining a retroactive statute as one that "purports to determine the legal significance of acts or events that have occurred prior to the date of its enactment"); Stephen R. Munzer, Retroactive Law, 6 J. LEGAL STUd. 373, 373 (1977) (defining a retroactive law as one that "alters the legal status of acts that were performed before it came into existence").

250. The definition would also include court decisions that apply to acts occurring before the decisions are announced. However, for the purposes of this Comment, the discussion will be limited to legislative rather than common-law retroactivity.

251. Louis Kaplow, An Economic Analysis of Legal Transitions, 99 HaRV. L. REv. 509, 515-16 (1986).

252. Society for the Propagation of the Gospel v. Wheeler, 22 F. Cas. 756, 767 (C.C.D.N.H. 1814) (No. 13,156).

253. See Elmer E. Sinead, The Rule Against Retroactive Legislation: A Basic Principle of Jurisprudence, 20 MiNN. L. REv. 775, 781-83 (1936).

254. W. David Slawson, Constitutional and Legislative Considerations in Retroactive Lawmaking, 48 CALIF. L. REv. 216, 218 (1960). In general, a nominally prospective law may be vested-rights retroactive "if, in the society in which the law will be effective, certain classes of individuals have unade substantial commitments of property or labor in anticipation of engaging in the proscribed conduct." Id.

255. See, e.g., FHA v. The Darlington, Inc., 358 U.S. 84, $90-92$ (1958) (analyzing retroactivity of a statute in terms of whether it affected vested rights); Ray A. Brown, Vested Rights and the 
This broad view of retroactivity could encompass the first two alternatives for applymg the proposed amendment. As an example, take the case of a 1970 movie based on a 1962 novel. When the novel entered its renewal term in 1990, the studio did not acquire the inotion picture rights for the renewal term and the film was withdrawn froin circulation as a result of Stewart. Assume that the proposed legislation becomes effective on January 1, 1993; it is to be apphed to all causes of action that accrue on or after that date (alternative (2)). In 1993 the inovie can be shown on television without liability. Although the amendment appears wholly prospective, there is a hidden elennent of retroactivity. The autlior's vested rights in the renewal term of his work are impaired; the value of his copyright is diminished to the extent of the fair market value of the inotion picture rights in the renewal term. Therefore, the author can argue that the legislation deprives him of property $m$ violation of the Due Process and Takings Clauses of the Fiftli Amendinent.

The objections to retroactive statutes are strong. Foremost among them is the belief that citizens should be able to plan their conduct with reasonable ccrtainty of the legal consequences. ${ }^{256} \mathrm{~A}$ retroactive statute creates instability with respect to past transactions and prevents an individual from planning and carrying out future conduct in accordance witl applicable law. Although the Constitution does not exphicitly guarantee an individual's ability to rely on the civil law, "nothing seems more basic to the existence of a legal order than the ability to rely upon the actions of others, including the government, with some assurance."257

These fairness considerations explam the historical judicial bias against retroactive legislation. However, courts have also recognized that "the legal order inust constantly change to fit new factual conditions or new conceptions of the common good."258 In 1822 one state court noted that "laws of a retroactive nature, affecting the rights of individuals, not adverse to equitable primciple, and highly promotive of the general good, have often been passed and as often approved" and questioned "whether there is an existing government, in which laws of a retroactive

Portal-to-Portal Act, 46 Mrch. L. Rev. 723, 733 (1948) ("Numerous decisions . . have held it beyond the constitutional power of the legislature to deprive a person of a right of action previously vested."). However, several commentators have recognized that the term "vest" is conclusory. See, e.g., Hochman, supra note 249, at 696 ("[A] right is vested when it has been so far perfected that it cannot be taken away by statnte."); Munzer, supra note 249 , at 382 n.15 (" [V]est' is a chameleon among legal words .....").

256. See Hochman, supra note 249, at 692; Munzer, supra note 249, at 391; Stephen R. Munzer, $A$ Theory of Retroactive Legislation, 61 TEx. L. REv. 425, 426 (1982) ("Retroactive laws frustratc the central purpose of law by disrupting expectations and actions taken in reliance on them.").

257. Slawson, supra note 254 , at 225 . For a thorough analysis of the grounds for the bias against retroactive legislation, see Bryant Smith, Retroactive Laws and Vested Rights (pt. 2), 6 TEx. L. REV. 409 (1928). For a comprehensive historical account of the bias, see Smead, supra note 253; see also Grecnblatt, supra note 249 , at 540-44 (examining the history of the bias).

258. Slawson, supra note 254 , at 226. 
nature and effect, impairing vested rights, but promotive of justice and the general good, have not been passed."259

Most importantly, that a piece of civil legislation is retroactiveeither in apphication or in effect-is not enough to render it unconstitutional. Although the traditional view regarded all retroactive legislation as suspect, ${ }^{260}$ modern courts acknowledge that retroactivity is a ground for holding a statute void only if it results in the violation of a specific constitutional provision. ${ }^{261}$ The Constitution contains two exphicit prohibitions against retroactive statutes: the Ex Post Facto Clause ${ }^{262}$ and the Contract Clause. ${ }^{263}$ These provisions, however, are of limited utility. The prohibition against ex post facto laws addresses only criminal statutes, ${ }^{264}$ and the clause forbidding legislation that impairs the obhgations of contracts apphies only to the states. Because retroactive civil legislation of the federal government is immune from challenge under both provisions, the Due Process and Takings Clauses of the Fifth Amendinent have been used to fill the gap. ${ }^{265}$

\section{a. The Due Process Clause}

The Supreune Court has never imterpreted the Due Process Clause to impose an absolute prohibition against retroactive legislation. ${ }^{266}$ Rather, the Court has recognized that in any particular case mitigating considerations might make a retroactive statute valid and desirable. The Court has invalidated as violative of due process only those retroactive statutes "which, upon a balancing of the considerations on both sides, are felt to be unreasonable." ${ }^{267}$ One influential article on retroactive legislation

259. Goshen v. Stonington, 4 Conn. 209, 221-22 (1822); see also cases cited in Greenblatt, supra note 249, at 540 n.2; Smead, supra note 253, at 785 n.36.

260. See, e.g., Dash v. Van Kleeck, 7 Johns. 477, 505-06 (N.Y. Sup. Ct. 1811) (discussing "a general and pointed condenunation of [retroactive] laws").

261. Hochman, supra note 249 , at 693-94.

262. U.S. CoNST. art. I, $\S 9$, cl. 3; id. art. I, $\S 10$, cl. 1 .

263. Id. art. I, § 10, cl. 1 .

264. Collins v. Youngblood, 110 S. Ct. 2715, 2719 n.2 (1990); see Calder v. Bull, 3 U.S. (3 Dall.) 386, 390-91 (1798).

265. Although the Due Process Clause of the Fourteenth Amendment is equally applicable, inost state legislation that violates that clause would also violate the prohibition against state legislation that inpairs the obligations of contracts. U.S. CoNST. art. I, $\S 10, \mathrm{cl}$. 1. Therefore, inost of the due process retroactive legislation cases are federal. JOHN E. NowAK ET AL., Constitutional LaW 385 (3d ed. 1986).

266. Cf. Chase Sec. Corp. v. Donaldson, 325 U.S. 304, 315 (1945) ("The Fourteenth Amendment does not inake an act of state legislation void merely because it has some retrospective operation.").

267. Hochman, supra note 249, at 694-95; see, e.g., Chase Sec. Corp., 325 U.S. at 315-16 (upholding against Fourteenth Amendment attack a state statute abolishing the statute of limitations defense in pending litigation); League v. Texas, 184 U.S. 156, 161-62 (1902) (upholding against Fourteenth Amendment challenge the application of new state procedures for collecting delinquent taxes to delinquencies occurring before enactment). 
suggests that the balance must be struck among three factors: "the nature and strength of the public interest served by the statute, the extent to which the statute modifies or abrogates the asserted preenactment riglit, and the nature of the right whicl the statute alters."268 The balance las been described elsewhere as comparing "the liarm to the objecting party [to] the gravity of the evil sought to be corrected by the legislature and the extent to which retroactivity of the statute is necessary to eradicate tliat evil."269

In Pension Benefit Guaranty Corp. v. R.A. Gray \& Co. ${ }^{270}$ the Court provided its first clear statement of the principles applicable to due process analysis of retroactive legislation:

Provided that the retroactive apphication of a statute is supported by a legitimate legislative purpose furthered by rational means, judgments about the wisdom of such legislation remain within the exclusive province of the legislative and executive branches. . . .

... [R]etroactive legislation does have to ineet a burden not faced by legislation that has only future effects. ... But that burden is inet simply by showing that the retroactive apphication of the legislation is itself justified by a rational legislative purpose. ${ }^{271}$

Under this deferential rational-relation test, retroactive acts slould rarely be invalidated on due process grounds. Although the Court will lold retroactive legislation unconstitutional if it concludes that the retroactivity serves no discerinible public purpose, ${ }^{272}$ it will likely upliold the statute when the imterests served by retroactive legislation are substantial and rationally related to the cliallenged legislation. ${ }^{273}$ The Court has found that even retroactive statutes that merely adjust the riglits between private groups can demonstrate sufficient public interest to pass constitutional muster. ${ }^{274}$

268. Hochman, supra note 249 , at 697.

269. William A. Reppy, Jr., Retroactivity of the 1975 California Community Property Reforms, 48 S. CAL. L. REV. 977, 1051 (1975).

270. 467 U.S. 717 (1984).

271. Id. at 729-30; see also National R.R. Passenger Corp. v. Atchison, T. \& S.F. Ry., 470 U.S. 451, 472 (1985) ("The party asserting a Fifth Amendment due process violation must overcome a presumption of constitutionality and " "establish that the legislature has acted in an arbitrary and irrational way." " " (quoting Pension Benefit Guar. Corp. v. R.A. Gray \& Co., 467 U.S. 717, 729 (1984) (quoting Usery v. Turner Elkhom Mining Co., 428 U.S. 1, 15 (1976)))).

272. See, e.g., Treigle v. Acme Homestead Ass'n, 297 U.S. 189, 197-98 (1936) (invalidating statute that for no discernible public purpose abrogated contracts that were lawful when made).

273. For example, in Usery v. Turner Elkhorn Mining Co., 428 U.S. I (1976), the Court sustained a federal statute that required coal mine operators to pay some of the benefits that Congress had granted to miners with black lung disease. The Court dismissed arguments that the mine operators might have relied on existing law, which inposed no liability, finding that the statute "approache[d] the problem of cost spreading rationally" and was therefore constitutional. Id. at 19; see also Chase Sec. Corp. v. Donaldson, 325 U.S. 304 (1945) (holding that state may repeal or extend statute of limitations and restore previously barred remedy to plaintifi).

274. For example, during the Depression the Supreme Court regularly upheld statutes that gave 


\section{b. The Takings Clause 275}

A related but separate challenge to any application of the proposed amendment that divests renewal owners of vested riglits is based on the Fiftl Amendment prohibition agamst the taking of private property for public use without just compensation. ${ }^{276}$ Although it is not immediately apparent that this provision applies to the proposed amendment because the benefit of any taking would accrue to private parties, ${ }^{277}$ the definition of "public use" has been expanded to include any takings that are beneficial or advantageous to the public. ${ }^{278}$ Recently, in Hawaii Housing Authority v. Midkiff, 279 the Court stated that the public use requirement is "coterminous witli tlie scope of a sovereign's police powers" 280 and is satisfied so long as the taking is "rationally related to a conceivable pubhic purpose."281

The "property" protected by the Takings Clause is not limited to land or other tangible assets. The Supreme Court has stated that property in the takings context denotes not the pliysical thing itself but ratler

relief to mortgagors at the expense of creditors. See, e.g., Gelfert v. National City Bank, 313 U.S. 221, 234-35 (1941) (holding that provision crediting judgment debtors with fair market value of foreclosed property when that exceeds the price the property brought at auction not inconsistent with rights of creditor-purchasers); Wright v. Union Cent. Life Ins. Co., 304 U.S. 502, 515-16 (1938) (holding that extension of redemption period on land sold at foreclosure sale is valid exercise of Congress' bankruptcy power); Hoine Bldg. \& Loan Ass'n v. Blaisdell, 290 U.S. 398, 445-46 (1934) (holding that extension of period of redemption not unconstitutional where statute safeguards interests of mortgagee-purchaser). But see FHA v. The Darlington, Inc., 358 U.S. 84, 98 (1958) (Harlan, J., dissenting) (criticizing retroactive application of a statute " 'designed to afford relief for private interests, as distinguished from public purposes" " (quoting The Darlington, Inc. v. FHA, 142 F. Supp. 341, 353 (E.D.S.C. 1956), rev'd, 352 U.S. 977 (1957))).

275. The jurisprudence of takings law is far too complex and unsettled to permit a thorought analysis of its application to the proposed amendment, let alone any definitive conclusions; an entire Coinment could be written on this issue alone. I attempt here only to give an overview of the doctrine and suggest low the precedents might indicate the resolution of the relevant criteria. For a comprehensive survey of the currently confused state of takings law, see Andrea L. Peterson, The Takings Clause: In Search of Underlying Principles (pt. 1), 77 CALIF. L. Rev. 1299 (1989).

276. U.S. CONST. amend. V.

277. 1 NIMMER \& NimMER, supra note $15, \S 1.11$, at 1-97.

278. See Comment, The Public Use Limitation on Eminent Domain: An Advance Requiem, 58 YALE L.J. 599, 610 \& n.63 (1949); see also cases cited id. passim. For example, in Berman v. Parker, 348 U.S. 26 (1954), a unanimous Court lield that the taking of property for sale to a redevelopinent agency, which would then lease or sell the land to private parties on condition that the purchasers would follow the redevelopment plan, was for a public rather than a private use. Id. at 33; see also Ruckelshaus v. Monsanto Co., 467 U.S. 986, 1014-16 (1984) (holding that statute providing for EPA's public disclosure of experimental data of applicant for pesticide registration when evaluating subsequent applications neets "public use" requirement, although "the most direct beneficiaries" will be later applicants who will not have to replicate research); Hawaii Hous. Autl. v. Midkiff, 467 U.S. 229, 239-44 (1984) (upholding against public-use attack a statute taking title in real property from lessors and transferring it to private lessees in order to reduce the concentration of ownership of fees simple within the state).

279. 467 U.S. 229 (1984).

280. Id. at 240 .

281. Id. at 241. 
"the group of rights inhering in the citizen's relation to the physical thing, as the right to possess, use and dispose of it."282 The Court has specifically held that the deprivation of a trade secret may constitute a taking, ${ }^{283}$ and the close analogy to the economically valuable proprietary interest in a copyright suggests similar treatment. ${ }^{284}$

Not every exercise of the police power that regulates owners' use of their property, even if the value of the property is thereby diminished, constitutes a compensable taking. As Justice Holmes stated in Pennsylvania Coal Co. v. Mahon:285

Government hardly could go on if to some extent values imcident to property could not be diminished without paying for every such change in the general law. As long recognized, some values are enjoyed under an implied limitation and must yield to the police power. But obviously the impled limitation must have its limits. ... One fact for consideration in determining such limits is the extent of the diminution. When it reaches a certain magnitude, im most if not in all cases there must be an exercise of eminent domain and compensation to sustain the act. ${ }^{286}$

This balancing of public and private interests suggests that regulations and takings exist on a continuum: where the regulation goes too far, it becoines a "taking" for which the injured owner inust be compensated. ${ }^{287}$

The precise manner in which the Court will draw the line between noncompensable regulations and coinpensable takings, however, "has proved to be a problem of considerable difficulty."288 Although the Court has stated that considerations of justice and fairness lie at the heart of this determination, ${ }^{289}$ it "has been unable to develop any 'set fornula' for determining when 'justice and fairness' require that economic injuries caused by public action be coinpensated by the government, rather than remain disproportionately concentrated on a few persons." 290

Two primary tests have been apphied to deterinine when a taking

282. United States v. General Motors Corp., 323 U.S. 373, 378 (1945).

283. Ruckelshaus v. Monsanto Co., 467 U.S. 986, 1001-04 (1984).

284. The Second Circuit has expressly stated that "[a]n interest in a copyright is a property right protected by the ... just compensation clause[ ]." Roth v. Pritikin, 710 F.2d 934, 939 (2d Cir.), cert. denied, 464 U.S. 961 (1983).

285. 260 U.S. 393 (1922).

286. Id. at 413.

287. NowAK et al., supra note $265, \S 11.12$, at 403 .

288. Penn Cent. Transp. Co. v. New York City, 438 U.S. 104, 123 (1978).

289. Armstrong v. United States, 364 U.S. 40, 49 (1960) (explaining that Takings Clause "was designed to bar Government from forcing sone people alone to bear public burdens which, in all fairness and justice, should be borne by the public as a whole").

290. Id. at 124; see also Connolly v. Pension Benefit Guar. Corp., 475 U.S. 211, 224 (1986) ("[W]e have eschewed the development of any set formula for identifying a 'taking' forbidden by the Fifth Amendnient, and have relied instead on ad hoc, factual inquiries into the circunistances of each particular case."); Agins v. City of Tiburon, 447 U.S. 255, 260-61 (1980) ("[N]o precise rule determines when property has been taken ...."). 
occurs. In Penn Central Transportation Co. v. New York City ${ }^{291}$ the Court identified three factors of "particular significance": the economic impact of the regulation on the claimant, the extent to which the regulation interferes with "distinct investment-backed expectations,"292 and the character of the governmental action. ${ }^{293}$ In Agins $v$. City of Tiburon ${ }^{294}$ the Court created an alternative two-part takings test, stating that a regulation constitutes a taking if it "does not substantially advance legitimate state interests or denies an owner economically viable use of his [property]."295 Although the Agins Court did not acknowledge that its test differed froin that of Penn Central (and in fact cited Penn Central as authority for the second criterion), later cases have stated that the Court will rely on the "no economically viable use" standard of Agins when dealing with a facial challenge to a statute and on the Penn Central test when faced with a challenge to a statute as apphed. ${ }^{296}$

A dominant consideration under either test is the extent to which the statute abrogates the preexisting property right. In several cases purporting to apply the Agins test, the Court ignored the "legitimate state interests" factor and focused exclusively on whether the regulation deprived the owner of any economically viable use of the property. ${ }^{297}$ Whether the "economic impact" factor of Penn Central or the "no economically viable use" factor of Agins is being apphed, the Court has indicated that it will not find a taking as long as the property in question can still be put to soine economically beneficial use. ${ }^{298}$ Moreover, in inaking such a determination the Court will generally look to the "parcel as a

291. 438 U.S. 104 (1978).

292. Subsequent formulations of the Penn Central test have substituted "reasonable" for "distinct," see, e.g., Williamson County Regional Planning Comm'n v. Hamilton Bank, 473 U.S. 172, 191 (1985); Ruckelshaus v. Monsanto Co., 467 U.S. 986, 1005 (1984), and the two phrases have even been used interchangeably within the same case, see, e.g., Connolly, 475 U.S. at 225, 226.

293. Penn Central, 438 U.S. at 124. Under the third prong of the test, a "physical invasion by government" is more likely to constitute a taking than is a "public program adjusting the benefits and burdens of economic life to promote the common good." Id.

294. 447 U.S. 255 (1980).

295. Id. at 260 (citation omitted).

296. See Keystone Bituminous Coal Ass'n v. DeBenedictis, 480 U.S. 470, 494-95 (1987); Hodel v. Virginia Surface Mining \& Reclamation Ass'n, 452 U.S. 264, 295-96 (1981). However, the Court has not consistently followed this rule, see, e.g., Nollan v. California Coastal Comm'n, 483 U.S. 825, 834 (1987) (applying the Agins test to an "as applied" challenge); Connolly v. Pension Benefit Guar. Corp., 475 U.S. 211, 224-25 (1986) (applying the Penn Central test to a facial challenge), and the grounds for the distinction have been criticized, see Peterson, supra note 275, at 1361 \& n.339.

297. See, e.g., Hodel v. Indiana, 452 U.S. 314, 335 (1981); Hodel v. Virginia Surface Mining, 452 U.S. at 296.

298. See, e.g., Hodel v. Indiana, 452 U.S. at 335; Hode1 v. Virginia Surface Mining, 452 U.S. at 296; Penn Cent. Transp. Co. v. New York City, 438 U.S. 104, 138 n.36 (1978). But see Keystone, 480 U.S. at 497 ("[O]ur test for regulatory taking requires ns to compare the value that has been taken from the property with the value that remains in the property ...."); Pennsylvania Coal Co. v. Mahon, 260 U.S. 393, 413 (1922) (stating that diminution in value becomes a taking "[w]hen it reaches a certain magnitude"). 
whole" rather than to a "discrete segment" of the property at issue. ${ }^{299}$

The same principles obtain in determining whether retroactive legislation effects a compensable taking of property or property rights. Courts have upheld inany retroactive statutes that diminished the value of real and personal property without compensation. ${ }^{300}$ The Court will be inore sympathetic to a statute whose retroactive apphication does not result in the complete destruction of preexistimg rights than it will be to laws that render existing rights virtually worthless. ${ }^{301}$

A leadimg takings scholar recently summarized the Court's takings doctrine by concluding that, apart from the separate category of "perinanent physical occupations" (which constitute takings per $\mathrm{se}^{\mathbf{3 0 2}}$ ), a regulation will be deemed a taking of property only if it "specifically undermines a 'distinct investment-backed expectation" " or "totally eliminates the property's economic value or 'viability' to its noininal owner."303

\section{Constitutional Analysis Applied}

Having set out the background of the retroactivity problem, this Section will analyze the respective benefits and constitutional vulnerability of each of the four alternatives for apphication of the amendinent. The discussion assumes an effective date of January 1, 1993.

299. Penn Central, 438 U.S. at 130-31; see also Andrus v. Allard, 444 U.S. 51, 65-66 (1979) ("[W] $]$ here an owner possesses a full 'bundle' of property rights, the destruction of one 'strand" of the bundle is not a taking, because the aggregate must be viewed in its entirety."). But see Nollan, 483 U.S. at 831 (holding that appropriation of public easement across private beachfront property is a taking requiring compensation).

300. See Munzer, supra note 256 , at 446 n.54.

301. See Hochman, supra note 249, at 714; cf. Energy Reserves Group, Inc. v. Kansas Power \& Light Co., 459 U.S. 400, 411 (1983) (stating in challenge under Contract Clause that "[t]he severity of the impairment ... . increase[s] the level of scrutiny to which the legislation will be subjected"). Compare Marcus Brown Holding Co. v. Feldinan, 256 U.S. 170 (1921) (upholding statute enacted during housing shortage that permitted lessee to remain after expiration of lease upon payinent of reasonable rental value) and Terry v. Anderson, 95 U.S. 628 (1877) (holding that legislature inay constitutionally shorten statutory period within which legal clain must be asserted) with W.B. Worthen Co. v. Kavanaugh, 295 U.S. 56, 62 (1935) (holding statute diminishing ability of bondholders to take possession of mortgaged lands without rent liability unconstitutional as it would result in "unnecessary destruction of nearly all the incidents that give attractiveness and value to collateral security") and Pennsylvania Coal Co. v. Mahon, 260 U.S. 393 (1922) (holding that state statute prohibiting coal mining that might cause subsidence of houses is unconstitutional as applied to coal company that had reserved rights to remove coal froin under land).

302. Loretto v. Teleproinpter Manhattan CATV Corp., 458 U.S. 419, 426 (1982).

303. Frank Michelman, Takings, 1987, 88 CoLUM. L. REv. 1600, 1622 (1988) (footnote omitted). 


\section{a. Application to Renewal Terms Commencing On or After the Effective Date}

The most limited approach would apply the amendment only to underlying works whose renewal terms commenced on or after January 1, 1993-that is, to works initially copyrighted between January 1, 1965, and December 31, 1977. This limitation, while likely to survive constitutional challenge, would greatly restrict the beneficial utility of the amendment in addressing the problems created by Stewart.

Apphed in this manner, the amendment would serve the desirable functions of reinstating the market for derivative rights im post-1964 works, currently considered out-of-bounds by derivative-work creators, and eliminating the studios' need to renegotiate grants of rights for such works upon commencement of their renewal terms. However, this application would leave unchanged the status of existmg motion pictures currently affected by Stewart. Any motion picture based on an underlying work copyrighted before 1965 and as far back as $1918^{304}$ would remaim dependent for its continued utilization on the acquisition of renewal-term rights. Without such acquisition, movies could still be withheld from the public until the year 2038, the last year im which an unaffected underlying copyright wonld expire. Furthermore, the amendment would do little to curtail the "copyright ambush" problem that prevents the use of certain public-domain inotion pictures; $;^{305}$ any motion picture based on a renewed pre-1965 work would be unavailable for unlicensed exhibition even when in the public domain.

Although its benefits would be limited, this apphication of tlie proposed amendment has the clearest chance of prevailing against constitutional attack because the Court is unlikely to view it as retroactive. The precise definition of retroactivity remains unclear, ${ }^{306}$ but under generally accepted primciples a law will not be deemed retroactive siniply because it affects property rights or expectations stemming from preenactinent action. ${ }^{307}$ This approacl is required because most substantial legislation will, to some degree, affect legal relations entered imto and rights acquired before its enactment. ${ }^{308}$ Thus, the Supreme Court exphicitly stated in $F H A$ v. The Darlington, Inc. ${ }^{309}$ that " [f]ederal regulation of

304. A work copyrighted in 1918 and renewed in 1946 would be in the last year of its fortyseven-year renewal term in 1993.

305. See supra text accoinpanying notes 67-73, 173-74.

306. See supra text accoinpanying notes 249-55.

307. See Munzer, supra note 256, at 426 (suggesting that prospective tax statute changing depreciation inethod for rental property would not be retroactive, although it might defeat expectations of individuals who purchased rental property with intent to take advantage of rapid depreciation under then-existing law).

308. See Slawson, supra note 254, at 235.

309. 358 U.S. 84 (1958). 
future action based upon rights previously acquired by the person regulated is not prohibited by the Constitution. So long as the Constitution authorizes the subsequently enacted legislation, the fact that its provisions limit or interfere with previously acquired rights does not condemn it." "'310

Furthermore, as the Court held in Miller Music Corp. v. Charles $N$. Daniels, Inc., ${ }^{311}$ the renewal right is an "unfulfilled expectancy" until it vests at the commenceinent of the renewal term. ${ }^{312}$ The underlying proprietor has no vested rights in the renewal term before the commenceinent of that term, and hence no claim that the legislation would deprive limi of vested rights. Thus, even under Justice Story's broad "vested rights" definition of retroactivity, ${ }^{313}$ this application of the amendinent would not be viewed as retroactive.

Compensable takings can occur even in the absence of retroactivity. ${ }^{314}$ Thus, the underlying-work proprietor might still argue that his rights in the renewal term of the work, mcluding the right to profit from the hicensing of the renewal rights to the derivative-work owner, cannot be abrogated by the government without just compensation. The arguinent that a inere expectancy, rather than a vested property right, is involved would be probleinatic here. Although the Court has frequently said that rights that are not "vested" are not property for purposes of the Takings Clause, ${ }^{315}$ "vesting" has different meanings for purposes of copyright transferability and takings analysis. When the Court speaks of "vested" and "nonvested" rights in takings cases, it seems to focus on whether the legislature has exphicitly or imphicitly reserved the right to change the claimant's legal rights. ${ }^{316}$ The reasoning is that "when the government grants $A$ a legal right, it normally retains the power to change the law to promote the general welfare, and thus no taking occurs when the government exercises its retained power, even though the change in the law eliminates $A$ 's rights under the prior law."317

It seeins clear that a copyright or any of the rights thereunder, even

310. Id. at 91 (quoting Fleming v. Rhodes, 331 U.S. 100, 107 (1947)); cf. United States v. Locke, 471 U.S. 84, 105 (1985) (stating that certain "vested economic rights are held subject to the Government's substantial power to regulate for the public good the conditions under which business is carried out and to redistribute the benefits and burdens of economic life").

311. 362 U.S. 373 (1960).

312. See supra text accompanying notes 34-37.

313. See supra text accompanying note 252.

314. See, eg., Nollan v. California Coastal Comm'n, 483 U.S. 825 (1987).

315. See, e.g., Bowen v. Public Agencies Opposed to Social Sec. Entrapment, 477 U.S. 41, 55 (1986) (holding amendment to Social Security Act barring states from witlidrawing employees does not effect a taking as superseded provision "simiply was part of a regulatory program over wlicls Congress retained authority to amend in the exercise of its power to provide for the general welfare" and thus "did not rise to the level of "property" ").

316. See Peterson, supra note 275, at 1349.

317. Id. at 1313. Professor Peterson observes that tlie Supreme Court's approacls suggests the 
those that are not "vested" for copyright purposes, constitute property for takings purposes. Copyrights, like patents ${ }^{318}$ and other intangibles such as trade secrets ${ }^{319}$, are eleinents of personal property. ${ }^{320}$ Although the renewal right does not vest until the commenceinent of the renewal term, it inay be transferred earher, and the transfer will be effective if the author survives until vesting. ${ }^{321}$ Thus, the argument that no property rights are involved is a weak one.

The question of whether the rights at issue constitute "property" under the Fifth Amendment, however, is separate froin the question of whether government deprivation of such property requires coinpensation. Although the "investinent-backed expectations" test of Penn Central would seein a inajor obstacle for retroactive legislation that diminishes the value of property rights, the requirenent that such expectations be "reasonable" has precluded recovery for changes of law in areas traditionally subject to changing pohicy and regulation. ${ }^{322}$ Thus, a history of flexibility in an area of law might be enough to make investinent-backed expectations in that area unreasonable, even if such flexibility is insufficient to defeat classification of the relevant interests as "property." 323 When parties are on notice (actual or constructive) that the legislature inay exercise its regulatory powers by adjusting and changing benefits or rights in a field in which it has coinpetence, rehance on the continuation of preexisting law might be considered per se unreasonable and retroactive apphication upheld. ${ }^{324}$

For example, in Bowen v. Gilliard ${ }^{325}$ the Court held that an amendinent to a social welfare program's governimg statute requiring, as a condition of ehgibility, that children of families receiving aid assign their

view that "ordinarily legislation only articulates current policy, and does not purport to bind the government in the future." Id. at 1314.

318. See 35 U.S.C. $\$ 261$ (1988) ("[P]atents shall have the attributes of personal property.").

319. See Ruckelshaus v. Monsanto Co., 467 U.S. 986, 1001-04 (1984) (holding that trade secret is property for purposes of Takings Clause).

320. See 1976 Act, 17 U.S.C. $\$ 201$ (d)(1) (1988) (providing that copyrights "may be transferred in whole or in part by any means of conveyance or by operation of law, and may be bequeathed by will or pass as personal property by the applicable laws of intestate succession").

321. See supra text accompanying notes 29-37.

322. See, e.g., Connolly v. Pension Benefit Guar. Corp., 475 U.S. 211, 227 (1986) (holding that amendment to ERISA, requiring an employer withdrawing from a multiemployer pension plan to pay fixed sums to the plan to fund vested benefits, does not effect a taking, as " ' $t$ ]hose wlio do business in the regulated field cannot object if the legislative sclieme is buttressed by subsequent amendments to achieve the legislative end" " (quoting FHA v. The Darlington, Inc., 358 U.S. 84, 91 (1958))).

323. Unfortunately, the Court does not always clearly distinguish between the questions of what constitutes "property" and which takings require compensation. See Peterson, supra note 275, at 1323 (noting that the Snpreme Court has used the "expectation imterest" test inconsistently to determine issues of "property" and "takings").

324. See Hochman, supra note 249, at 700; Reppy, supra note 269, at 1050.

325. 483 U.S. 587 (1987). 
child-support claims to the government did not constitute a taking despite the amendment's clear interference with economically valuable rights. Reasoning that "Congress is not, by virtue of having instituted a social welfare program, bound to continue it at all, inuch less at the saine benefit level," 326 the Court held that "[a]ny right to have the State force a noncustodial parent to inake payments is, like so inany other legal rights . . . subject to modification by 'the pubhic acts of government." "327

Similarly, in Ruckelshaus v. Monsanto Co. ${ }^{328}$ the Court held that absent an express promise, a submitter of trade-secret information had no reasonable, investment-backed expectation that its information would remain undisclosed by the EPA. The Court noted that "[i]n an industry that long has been the focus of great pubhic concern and significant government regulation, the possibility was substantial that the Federal Government, . . . upon focusing on the issue, would find disclosure to be in the public imterest."329 Even the Trade Secrets Act (which provides criminal penalties for government employees who make unauthorized disclosures of trade secret information) was held to provide no guarantee of confidentiality to submitters of data. ${ }^{330}$

The rationale of Ruckelshaus is particularly persuasive with respect to the proposed amendment. The Constitution grants Congress the power to enact copyright legislation to serve a specific goal: "promot[img] the Progress of Science and Useful Arts."331 Copyright holders can have no reasonable expectation that Congress will not ainend the Copyright Act if the current legislation falls short of achieving this end. ${ }^{332}$ As Charles Hochman notes,

when Congress has the substantive power to act prospectively, the public interest in the effectiveness of the legislative scheine seeins clearly to permit the elimination of pre-existing evils which inay have pointed up the very need for the legislation and whose continued existence would impair the effectiveness of the statntory scheme. ${ }^{333}$

If the Court were to apply the "no economically viable use" test of Agins imstead of the "investment-backed expectations" test of Penn Central, the result would be the saine. For the purposes of the Agins test,

326. Id. at 604 .

327. Id. at 608 (quoting Reichelderfer v. Quinn, 287 U.S. 315, 319 (1932)).

328. 467 U.S. 986 (1984).

329. Id. at $1008-09$.

330. Id. at 1008. However, in the same case the Court found that the statutory amendments permitting data disclosure did effect a taking with respect to information submitted at a time when the law had explicitly guaranteed confidentiality. Id. at 1011.

331. U.S. CoNST. art. I, § 8, c1. 8.

332. Cf. Connolly v. Pension Benefit Guar. Corp., 475 U.S. 211, 227 (1986) (holding that ERISA amendments do not effect taking because statute is subject to alteration to achicve its purpose).

333. Hochman, supra note 249 , at 702 . 
the Court defines the property at issue as the parcel as a whole ${ }^{334}$-in this case, the entire "bundle of rights" that constitutes a copyright. The devaluation of the renewal copyright is only partial. As discussed earlier, the proposed amendment would not render the property of the sourcework owner valueless, and the value miglit even be increased by a successful derivative work. ${ }^{335}$

In his influential study of takings law, Professor Michelman concludes that the only true test of coinpensability that is consistent with the purpose of the Takings Clause is fairness: "[I]s it fair to effectuate this social ineasure without granting this claim to compensation for private loss thereby inflicted?" 336 Michelman identifies four factors, one of which is usually critical in determining whether coinpensation is constitutionally required:

(1) whether or not the public or its agents liave pliysically used or occupied something belonging to the claimant; (2) the size of the harm sustained by the claimant or the degree to which his affected property has been devalued; (3) whether the claimant's loss is or is not outweigled by the public's concomitant gain; (4) whetlier the claimant lias sustained any loss apart from restriction of his liberty to conduct some activity considered harmful to other people. ${ }^{337}$

The fourth factor refers to the power to regulate public nuisances (the "noxious use" rationale) $)^{338}$ and is not relevant to this analysis. However, the preceding discussion has atteinpted to show that the first three factors, as well as the inore general "fairness" test, all support the conclusion that the amendment could be applied so as to diminish the value of the property of renewal expectancy holders without the payment of coinpensation.

\section{b. Application to Causes of Action Arising On or After the Effective Date}

The amendment's scope would be significantly expanded by applying it to all causes of action arising on or after January 1, 1993, regardless of when the renewal term of the underlying work began. This would permit the exhibition of inany inotion pictures currently vulnerable to a Stewart v. Abend problein without fear of liability for infringenent. The cure would not be coinprehensive, lowever. Because section 304(a)

334. See supra note 299 and accompanying text.

335. See supra text accompanying notes $219-20$.

336. Frank I. Michelman, Property, Utility, and Fairness: Comments on the Ethical Foundations of "Just Compensation" Law, 80 HARv. L. Rev. 1165, 1172 (1967); see Peterson, supra note 275, at 1342 (suggesting that the Justices of the Supreme Court "are ultimately deciding takings cases by relying on their sense of when fairness requires the paynent of compensation, even though the Court's current takings tests do not directly address the fairness issue").

337. Michelman, supra note 336, at 1184.

338. See, e.g., Miller v. Schoene, 276 U.S. 272 (1928). 
apphes only to copyrights in their first term on January 1, 1978 (the effective date of the $1976 \mathrm{Act}$ ), the amendinent's protection would extend only to inovies based on works whose renewal terms commenced on or after that date-that is, to underlying works originally copyrighted between January 1, 1950, and December 31, 1977. Nevertheless, a inotion picture based on a work covered by the amendment could be freely exploited by its proprietor without regard to the copyright status of the underlying work, and once in the public domain it would be available to the public without fear of infringement.

Although this approach, like the previous one, is nominally prospective, and better redresses the negative policy effects of Stewart, its constitutional infirmity might be more difficult to overcome. Apphied in this way, the amendment would have a retroactive impact on previous imvestments and forined expectations; it could leave owners of vested renewal rights-original authors, purchasers, and statutory successors who have renewed their copyrights-with property of significantly diminished value. Nevertheless, this application would probably be constitutional.

The proposed amendment, apphed to all causes of action accruing after its enactment, would likely withstand a due process challenge. The rational-relation test announced by the Court in Pension Benefit Guaranty Corp. v. R.A. Gray \& Co. ${ }^{339}$ presents an easy hurdle for an amendinent designed to prevent the severe harm to the public interest shown in Part II of this Comment. A legislative purpose that brings the Copyright Act inore into accord with the constitutionally specified aims of copyright legislation is clearly legitimate, and the amendment is rationally related to the effectuation of this purpose. ${ }^{340}$

339. 467 U.S. 717 (1984); see supra text accompanying note 271.

340. If the amendment could be classified as "curative," it would be entitled to the favorable treatment traditionally accorded to such legislation. Temple Univ. v. United States, 769 F.2d 126, 134 (3d Cir. 1985), cert. denied, 476 U.S. 1182 (1986). A curative statute is one that restores the original legislative intent of a statute by removing an unintentional flaw, often brought to light by an unexpected court decision. See Smead, supra note 253 , at 786 n.36. In such cases the original legislative purpose is consistently viewed as sufficient to justify retroactivity, Hochnan, supra note 249 , at 704, and such statutes are virtually always sustained under due process analysis, see id. at 705 ("It is necessary that the legislature should be able to cure inadvertent defects in statutes or their administration by making what has been aptly called 'small repairs.' "); id. at 705-06 ("[T]he interest in the retroactive curing of such a defect in the administration of government outweighs the individual's interest in beneffing from the defect."). An example is the Portal-to-Portal Act of 1947, which responded to the Court's unforeseen interpretation of the Fair Labor Standards Act (FLSA) by eliminating both the right to sue for overtime wages and the jurisdiction of the courts to hear such claims. The Act was retroactive in effect but was uniformly sustained by the courts against constitutional challenges as a curative statute that gave effect to the original congressional intent behind the FLSA. See generally Grecnblatt, supra note 249, at 554-57 (discussing the Portal-toPortal Act).

However, classification of this amendinent as "curative" is unlikely. The Court's reading of the renewal and derivative-works provisions of the 1909 Act is a tenable accommodation of those sections. Furthermore, despite the legislative history suggesting congressional sensitivity to the 
This application of the amendment also liolds up under a takings analysis. With the broad public-use requirement as defined in Hawaii Housing Authority v. Midkiff ${ }^{341}$ apparently met by the proposed amendment, the inquiry would focus on whether underlying renewal rights may be transferred to derivative-work owners without payinent of compensation. The application of the amendinent to all causes of action accruing subsequent to its enactinent would arguably constitute a valid regulatory exercise of the police power ratler than a compensable taking. The legislation does not involve the taking by the government of title to the renewal holder's property, but ratlier the regulation of that property's use. No transfer of copyright ownership would occur. Thus, the situation at issue is similar to that of zoning and landmark-preservation regulations, which rarely constitute takings. ${ }^{342}$

Transfer of title is not a prerequisite for establishing a compensable taking. ${ }^{343}$ Nevertheless, "the character of the governmental action" is a component of the Penn Central test, ${ }^{344}$ and the Court in that case explamed that "[a] 'taking' inay inore readily be found when the interference with property can be characterized as a physical invasion by governinent than when interference arises froin some public program adjusting the benefits and burdens of economic life to promote the common good."345 Altlough the "physical mvasion" language is ill-suited to intangibles such as copyrights, the effects of the proposed amendment would inore resemble an adjustment of benefits and burdens than a wholesale government appropriation of property rights.

For the reasons stated above in the discussion of the previous retroactive alternative, the amendment does not effect a taking under the "no economically viable use" test. ${ }^{346}$ Nor would a compensable taking exist under the "reasonable investment-backed expectations" standard. As copyright law has historically been subject to periodic revisions as required to effect its constitutionally mandated goals, it would be difficult

special situation of derivative works, there is no explicit statennent of intent to exempt these works froin the renewal provision of $\$ 304($ a) of the 1976 Act. See supra notes 231-46 and accoinpanying text. This is not a situation like the Portal-to-Portal Act, where the Court's unanticipated reading of the statute was clearly contrary to legislative intent.

341. 467 U.S. 229 (1984); see supra text accoinpanying notes 279-81.

342. See, e.g., Penn Cent. Transp. Co. v. New York City, 438 U.S. 104 (1978) (holding that denial of property owner's right to construct office building above landinark terminal does not constitute a taking); Goldblatt v. Town of Heinpstead, 369 U.S. 590, 595 (1962) (holding that zoning ordinances do not constitute takings if public interest requires sucl interference and "the means are reasonably necessary for the accomplishment of the purpose, and not unduly oppressive' " (quoting Lawton v. Steele, 152 U.S. 133, 137 (1894))).

343. See, e.g., Hodel v. Irving, 481 U.S. 704 (1987) (holding that federal statute prohibiting devise or descent of interests in real property effects a taking of decedents' property).

344. Penn Central, 438 U.S. at 124.

345. Id. (citation omitted).

346. See supra text accompanying notes 334-35. 
for any holder of even a vested copyright interest to show a reasonable expectation that a particular statutory provision or judicial construction would remain unchanged.

Although past purchasers of renewal rights might argue that any apphication of the amendment that divests them of the value of their acquired property constitutes a taking of their contractual assets, the Court has made clear that contracts in areas subject to the regulatory powers of the legislature inay be legitimately affected by the exercise of those powers. ${ }^{347}$ As Chief Justice Hughes stated:

Contracts, however express, cannot fetter the constitutional authority of the Congress. Contracts may create rights of property, but when contracts deal with a subject matter which hes within the control of the Congress, they have a congenital infirmity. Parties cannot remove their transactions from the reach of dominant constitutional power by making contracts about them. ${ }^{348}$

\section{c. Application to All Causes of Action Involving Copyright Renewals Under the 1976 Act}

If the proposed amendinent would be viable as applied to postenactment causes of action notwithstanding the accompanying diminution in value of the renewal rights, it seems but a small step to assert the amendinent's constitutionality as apphed to any preenactment utilization of derivative works. The underlying and derivative works affected by this apphication would be the same as those affected by the previous alternative. The only difference is that this approach would protect those derivative-work owners and nembers of the pubhc who, unwittingly or otherwise, exploit derivative works in violation of the underlying copyright prior to the effective date.

Under the Pennsylvania Coal Co. balancing test, ${ }^{349}$ a noncompensable regulation becomes a coinpensable taking when the diminution in value reaches a certain magnitude. If the difference between a taking and a regulation is itself a matter of degree, it is of course not dispositive of the takings analysis that the difference between this alternative and the prior one is of degree ouly. Nevertheless, the difference here is not likely to be significant enough to affect the outcome.

There is one potentially significant difference, however, between this option and the previous retroactive alternative. Here, for the first time, we are faced with government going into pendimg cases and tellimg plaintiffs that they no longer have a case. Although this is arguably a very different situation frow the prospective elimination of a cause of action

347. See Hochman, supra note 249 , at 700.

348. Norman v. Baltimore \& O.R.R., 294 U.S. 240, 307-08 (1935).

349. See supra text accompanying notes 285-87. 
before it arises, similar legislation has previously been upheld in some circumstances. ${ }^{350}$ While it is impossible to predict the response of Congress or the Court in this instance, it is arguable that if the previous alternative would be constitutional under the minimal due-process requirements and the various takings tests, the timing of the alleged infringement should not substantially affect the analysis. The rights and expectancies affected, the economic harm to the underlying-work owner, the reasonableness of any investment-backed expectations, the residual value of the underlying copyright, and the benefit to the public are unclianged. Furthermore, including an amnesty for preenactment exhibitions within the amendment might make some derivative-work owners less likely to withdraw their works from the public during the possibly long enactment process.

\section{d. Application to All Existing Underlying Works}

Even the broad retroactive effects of the previous alternative would leave a significant loophole in the protection of derivative-work owners. Because section 304(a) of the 1976 Act applies only to copyriglits subsisting in their first term on January 1, 1978, the amended section would not cliange the treatment of underlying works that were renewed under the provisions of the 1909 Act. Thus, all motion pictures based on those works (including Rear Window) would still be governed by the vague language of sections 7 and 24 of the 1909 Act as interpreted by the Supreme Court in Stewart. ${ }^{351}$

350. An example is the Portal-to-Portal Act, which was upheld as a constitutionally valid curative statute despite the Act's elimination of pending causes of action. See supra note 340. Congress has even passed such legislation outside the "curative" context. For example, during the hearings on the Warner Amendment, which allowed the government to substitute itself as defendant in pending damage suits against contractors for injuries resulting from atomic-bomb tests (thereafter asserting sovereign immunity and forcing dismissal of the suits), the House Judiciary Committee expressed concern that the amendinent " would eliminate property interests in pending causes of action in violation of the fifth amendinent.'" William A. Fletcher, Atomic Bomb Testing and the Warner Amendment: A Violation of the Separation of Powers, 65 WASH. L. REv. 285, 306 n. 107 (1990) (quoting House COMM. ON THE ARMEd SERVS., DEP'T OF ENERGY, NAT'L SECURITY AND Military Applications of Nuclear ENERgy Authorizations Act of 1984, H.R. ReP. No. 124, 98th Cong., 1st Sess., pt. 4, at 5 (1983) (Adverse Report submitted by S. Hall, House Committee on the Judiciary). Nevertheless, the Warner Amendment was approved by both houses without debate and was signed iuto law by President Reagan in 1984, and the Supreme Court demed certiorari when pendiug legislation was subsequently dismissed upon the government's sovereign immumity defense. Fletcher, supra, at 308. Congress has so far resisted a movement to repeal the Amendment.

351. The often difficult question of which Act applies in a given case would therefore be of paramount significance. Copyright disputes are "governed by title 17 as it existed when the cause of action arose." Transitional and Supplementary Provision $\$ 112,90$ Stat. 254.(1976), reprinted in 1976 HOUSE REPORT, supra note 16, at 46. However, the question of when the cause of action arose may be open to different answers. The Stewart majority declined to resolve this issue, finding that an interpretation of $\S 24$ of the 1909 Act would be required in either case (due to that section's reenactment in $\S 203$ of the 1976 Act). Stewart v. Abend, 110 S. Ct. 1750, 1758 (1990). Compare id. 
Congress could close this loophole by creating a universal derivative-works exception to the renewal provisions. This could be accomphished in two ways. First, Congress could simultaneously annend section 304(b) of the 1976 Act, which deals with the extension of copyright for those works in their renewal term before January 1, 1978, to permit derivative-work proprietors to utilize their works according to the initial grants. ${ }^{352}$ Second, Congress could simply determine that the amended version of section 304(a) is to be applied retroactively to affect the relative rights of derivative-work owners and holders of underlyingwork copyrights renewed under the 1909 Act. Either of these alternatives would involve the use of the 1976 Act to reach back and affect rights acquired and transactions entered into under the provisions of the superseded 1909 statute. Although the 1976 Act does not apply to causes of action arising prior to January $1,1978,353$ it is less clear whether the current Act is to be apphied retroactively to pre-1978 conduct, in causes of action arising on or after the effective date, where its definitions would result in a different finding of copyright ownership than under the 1909 Act. $^{354}$ For example, the different defiuntions of joint works and works made for hire under the two Acts would result in disparate determinations of ownership depending on which Act was applied: In causes of action arising under the 1976 Act, which definitions control? ${ }^{355}$

Courts have touched on this issue since the revision without ever definitively resolving whether retroactive apphication of the 1976 Act would be a constitutional violation. ${ }^{356}$ The Second Circuit provided the

at $1769 \mathrm{n} .1$ (Stevens, J., dissenting) (stating that property rights between litigants are determined by Woolricli's statutory grant under the 1909 Act) with Colby, supra note 92, at 595 (contending tliat 1976 Act should govern because cause of action arose witl 1982 reissue of Rear Window and movie's copyright was renewed under 1976 Act).

352. The amendment could provide either (1) that proprietors of derivative works are free to utilize those works according to the imitial grants ouly during the 19-year extension period tacked on by the section, or (2) that derivative-work proprietors remain free to utilize their works during the full renewal term of the underlying work. The first version would be retroactive for any underlying work that entered the extension period between January 1, 1978, and January 1, 1993, and the second version would be retroactive for all works renewed under the provisions of the 1909 Act. The more limited option would leave the possibility of suits for past infringements (tlat is, infringements occurring during the first 28 years of the underlying work's renewal term).

353. 1976 Act, 17 U.S.C. $\$ 301(b)(2)$ (1988); see 1 NIMMER \& NiMMER, supra note 15, $\S 1.01[\mathrm{~B}][3]$, at $1-28$.

354. 1 NIMMER \& NIMMER, supra note $15, \S 1.11$, at 1-95.

355. See id.

356. See, e.g., May v. Morganelli-Heumann \& Assocs., 618 F.2d 1363, 1368 n.4 (9tlı Cir. 1980) (refusing to apply 1976 Act's work-for-hire definition to pre-1978 cause of action); Rand McNally \& Co. v. Fleet Mgmt. Sys., 591 F. Supp. 726, 737 (N.D. Ill. 1983) (applying 1976 Act's work-for-lire definition to works protected by common-law copyright before January 1, 1978); Lieberman v. Estate of Chayefsky, 535 F. Supp. 90, 91 n.3 (S.D.N.Y. 1982) (applying 1976 Act's joint-work definition to novel existing in draft form before 1978 but published in 1978); Meltzer v. Zoller, $520 \mathrm{~F}$. 
most authoritative answer in Roth $v$. Pritikin, ${ }^{357}$ a case in which the plaintiff urged retroactive apphication of the 1976 Act's work-for-hire definition. In support of her claim, the plaintiff relied on section 301(a) of the 1976 Act, which provides:

On and after January 1, 1978, all legal or equitable rights that are equivalent to any of the exclusive rights within the general scope of copyright as specified by section 106 in works of authorship that are fixed in a tangible medium of expression and come within the subject inatter of copyright as specified by sections 102 and 103, whether created before or after that date and whether pubhshed or unpubhished, are governed exclusively by this title. ${ }^{358}$

The plaintiff claimed that this section demonstrated Congress' intent to apply all provisions of the 1976 Act to all copyrights in effect on the date of its enactinent. ${ }^{359}$

The court refused to apply the 1976 Act retroactively. It concluded that the statutory language meant that the exclusive rights set forth in the 1976 Act could be asserted in post- 1978 causes of action even regarding works created before 1978 , but not that the ownership of pre-1978 copyrights would be determined by the new Act. ${ }^{360}$ The court noted in dicta that adoption of the plaintiff's interpretation of section 301 would raise potential constitutional problems as resulting in takings of property without due process or just compensation. ${ }^{361}$

Under the Roth interpretation of the 1976 Act's applicability, the retroactive operation of the annended section 304 appears to be constitutional. The ainendment does not deal with a transfer of ownership of copyright or any of the bundle of rights included therem but rather with a determination of the scope of rights afforded to holders of copyrights in underlying and derivative works. The Roth court interpreted section 301 to mean that "[w]hoever holds an interest in a copyright on or after January 1,1978 , has a right to the protections afforded by the new statute, although the creative work may previously have been governed by the 1909 Act or the common law."362 Thus, the holder of copyright in a pre1978 motion picture would possess all rights granted to it under the 1976 Act, including the right to continue utilizing the work absent a grant of underlying renewal rights.

Supp. 847, 854 (D.N.J. 1981) (applying 1976 Act's work-for-hire definition to designs prepared in 1977 but infringed in 1978).

357. 710 F.2d 934 (2d Cir.), cert. denied, 464 U.S. 961 (1983).

358. 1976 Act, 17 U.S.C. $\$ 301$ (a) (1988) (emphasis added).

359. Roth, 710 F.2d at 938.

360. Id. ("Section 301 does not . . purport to determine who holds a copyright for works created before January 1978. It merely clarifies the rights of individuals owning copyrights on that date, whoinever they may be.").

361. Id. at 939 .

362. Id. at 938 . 
Although Nimmer points out in his discussion of retroactive application of the 1976 Act that "the paradigm case to illustrate unconstitutional retroactivity, and one not often encountered outside of theoretical discussions, occurs where a legislature purports to 'take the property of $A$ and transfer it to $B$ by a inere legislative act," "\$63 that constitutional infirmity is not present here. Nimmer is discussing retroactive apphication that results in an involuntary transfer of copyright ownership, and is thus in accord with Roth. In the situation at issue here, in contrast, the amendment would inerely affect the scope of a right previously granted to the derivative-work owner; the exclusive right to authorize derivative works would reinam the sole property of the holder of the renewal term in the underlying work.

This is not to suggest that the constitutionality of such far-reaching retroactive apphication is a clear-cut case. This alternative might in fact create virtually insurmountable difficulties, voiding countless transactions and contracts transferring renewal rights to derivative-work proprietors. The due process concerns that are justifiably outweighed by the strong public purpose in amending the 1976 Act might be overwhelming and unbeatable when amplified by untrammelled retroactive apphication. The amendment, while still technically falling short of the "no economically viable use" test, might so significantly interfere with the mvestmentbacked expectations of claimants as to constitute a taking requiring compensation. Faced with the possibly high cost of an erroneous judginent, ${ }^{364}$ the $e^{-}$confused and unpredictable nature of takings jurisprudence, ${ }^{365}$ and a Court that is increasingly conservative on property issues, Congress inay reasonably be hesitant to risk such a sweeping change in the law. Nevertheless, this Section has attempted to show that due process and takings protections do not provide an absolute bar to even the broadest apphication of the proposed amendinent.

It is important to note that even the broadest apphication of the amendment set forth in alternative (4) would not erase all effects of the Stewart decision. Because motion pictures, as works made for hire, are granted a copyright term of seventy-five years under the 1976 Act, $^{366}$ while underlying literary works (if not anonymous or pseudonyınous)

363. 1 NimMER \& NIMMER, supra note $15, \S 1.11$, at $1-96$ (quoting STORY ON THE CONSTITUTION $\S 1399$ (5th ed. 1891)).

364. In First English Evangelical Lutheran Church v. County of L.A., 482 U.S. 304 (1987), the Court lield that if a regulation is ultimately invalidated on takings grounds, the government must pay compensation for the period the taking was effective. The holding, however, was limited to takings that deprive the owner of all use of the property. Id. at 321 .

365. See supra note 275.

366. 1976 Act, 17 U.S.C. $\S 302$ (c) (1988). 
receive protection for the life of the author plus fifty years, ${ }^{367}$ the "copyright ambush" problem will continue indefinitely. Each time an author survives by more than twenty-five years the creation of a motion picture based on her work, the motion picture will enter the public domain while the source work is still protected, thus frustrating the public-domain policies of the Act and subjecting unsuspecting exhibitors of the film to liability for infringement of the underlying work. ${ }^{368}$ While this is technically not a Stewart problem because it does not involve the renewal terin, it is a consequence of that case's endorsement of the subordination theory and rejection of the new-property-right theory. This effect would not be diminished by the proposed amendment and might be curable only by a Supreme Court decision overruling Stewart.

\section{Other Potential Solutions}

The preceding discussion argued that even the broadest retroactive application of the proposed amendment to section 304(a) accords with Fifth Amendment guarantees. Sliould Congress balk at the prospect of such a dramatic solution, however, other possibilities for limiting the effects of Stewart through legislation exist. Two of these possibilities will be briefly discussed: the granting to the derivative-work owner of a compulsory license for use of the underlying work during its renewal term, and the limitation of available remedies to damages rather than imjunctive relief. The question of which works would be covered by these approaches raises tlie same issues as have been discussed throughout this Section.

\section{Compulsory Licensing}

If Congress is concerned with compensating underlying-work proprietors for the revocation of the proprietors' ability to renegotiate grants of derivative rights when their works enter their renewal tern, it could require renewal owners to hicense the right to contmue exploiting the derivative work upon tlie payment of a fixed sum by the derivative-work proprietor. Such coinpulsory licensing schemes already exist under the 1976 Act in four situations: the secondary transmission of broadcast signals by cable systems; ${ }^{369}$ the making and distribution of phonorecords of certain musical works; ${ }^{370}$ the public performance of musical works on jukeboxes; ${ }^{371}$ and the performance and display of works of art and music

367. Id. §302(a).

368. See supra text accompanying notes 173-74.

369. 1976 Act, 17 U.S.C. § 111(c) (1988).

370. Id. § 115 .

371. Id. § 116(a), (b). 
on public broadcasting stations. ${ }^{372}$

The objectives listed in the Act with respect to ratesetting for the plionorecord and jukebox exceptions suggest that a similar compulsory licensing provision would be appropriate for derivative renewal riglits in prelicensed underlying works. These objectives are:

(A) To maximize the availability of creative works to the public;

(B) To afford the copyright owner a fair return for his creative work and the copyright user a fair mcome under existimg economic conditions;

(C) To reflect the relative roles of the copyright owner and the copyright user in the product made available to the public with respect to relative creative contribution, technological contribution, capital imvestment, cost, risk, and contribution to the opening of new markets for creative expression and media for their commumication;

(D) To minimize any disruptive impact on the structure of the mdustries imvolved and on generally prevailing industry practices. ${ }^{373}$

Minimum royalties could be determined based on fixed percentages of gross receipts of the derivative motion picture during the underlying work's initial term; ${ }^{374}$ the Copyright Royalty Tribunal ${ }^{375}$ could promulgate these percentages witl the above objectives $\mathrm{m}$ mind. The fixed royalty itself could be compulsory or serve inerely as a backup in the event that private negotiations fail (as in the case of the compulsory license for public broadcasting under section 118)..$^{376}$

\section{Limitation of Remedies}

Congress could also elect legislatively to foreclose injunctive remedies for infrimgeinents of the type involved in Stewart. The Nintli Circuit found that the "special circumstances" of the collaborative effort that results in a inotion picture made the granting of an injunction against Rear Window's continued exhibition mappropriate. ${ }^{377}$ The court reasoned that because tlie defendants' protectable "new matter" was inseparable froin the underlymg work, an mjunction would render meaningless

372. Id. $\S 118$.

373. Id. $\S 801(\mathrm{~b})(1)$.

374. No one familiar with studio accounting practices would permit such a royalty to be determined by reference to net profits. $C f$. Buchwald v. Paramount Pictures Corp., 90 Daily Journal D.A.R. 14482 (L.A. Super. Ct. 1990) (holding Paramount's net-profit formula to be unconscionable).

375. The Copyright Royalty Tribunal is an adininistrative body created by the 1976 Act for the purposes of setting and adjusting reasonable terms and rates of compulsory royalty payments. Copyright Revision Act of 1976, 17 U.S.C. $\$ 801$ (1988). See generally E. Fulton Brylawski, The Copyright Royalty Tribunal, 24 UCLA L. REV. 1265 (1977).

376. For an alternative view that the derivative-works exceptions should be subject to a compulsory license, see R.D. Smith, Note, Rohauer v. Killiam Shows, Inc. and the Derivative Work Exception to the Termination Right: Inequitable Anomalies Under Copyright Law, 52 S. CAL. L. REv. 635, 659-62 (1979).

377. Abend v. MCA, Inc., 863 F.2d 1465, 1479 (9th Cir. 1988), aff'd, 110 S. Ct. 1750 (1990). 
their right to enjoy what rights their copyright gave them. The court also noted that "an mjunction could cause public mjury by denying the public the opportunity to view a classic film for many years to come."”378

The benefits of limiting injunctive relief would be extreinely sunall; studios would continue to avoid underlying works in their initial term and would continue their cost-benefit analysis as to whether renegotiation for renewal rights (or, possibly, knowing infringement) was a profitable venture. This approacli, however, would at least prevent the forced withdrawal of films inadvertently exhibited in violation of protected underlyimg works.

\section{CONCLUSION}

I confess that when I first read this psycho Rear Window opinion, I was in such a frenzy that I felt vertigo. It seems clear beyond a shadow of a doubt that the wrong man won. The trouble with Harry Pregerson and Justice O'Connor's approach is that it lets an underlying author or his family plot to sabotage classic movies that have held the public spellbound for decades when they have no more of a relationship with the filmmakers than strangers on a train. I have a suspicion that the thirtynine steps the court had to go througli to give this notorious saboteur the rope he needed to blackmail the defendants should have been directed mstead towards trying to catch a thief. In short, this opinion is for the birds. ${ }^{379}$

The unexpected decision in Stewart v. Abend and the undesirable consequences flowing from that decision can realistically only be stemmed at this poimt by legislative action. This Comment explored the reasons why Congress should consider remedymg the situation created by Stewart and proposed a possible cure. It also argued that the serious and inequitable effects of Stewart can only be eliminated by retroactive apphication of the proposed legislation and that such retroactivity accords with constitutional protections. Congress must respond to the Stewart decision quickly, before an untold number of classic American motion pictures are demied to new generations of fans.

378. Id. The issue of remedy was not before the Supreme Court in Stewart, and the Court declined to comment on it. Stewart v. Abend, 110 S. Ct. 1750, 1757, 1768 (1990). Ninmer believes that the Supreme Court's sidestepping of the remedy issue constituted "sub silentio approval of the Ninth Circuit approach." 1 NIMMER \& NIMMER, supra note $15, \S 3.07$ [A], at 3-47.

379. With apologies to Judge Kozinski (see United States v. Syufy Enters., 903 F.2d 659 (9th Cir. 1990)). 
